\title{
Edukacja międzykulturowa jako ćwiczenie duchowe. Pedagogiczne wymiary kształtowania kultury duchowej i rozumienia wartości ponadkulturowych w kontekście zróżnicowania religijnego i pluralizmu światopoglądowego
}

Streszczenie: W programowych wypowiedziach o edukacji międzykulturowej, wskazujących na jej zasadnicze cele i powinności, przyjmuje się, że należy do nich również poszukiwanie wartości mających wymiar uniwersalny, kształtowanie umiejętności komunikowania międzykulturowego, co wymaga przekraczania granic własnej kultury, wychodzenia na wielokulturowe pogranicza zróżnicowania religijnego i pluralizmu światopoglądowego. Uwzględnia się przy tym przemianę (przemianę duchową), która powinna zachodzić w kimś, kto przyjmuje za własne cele i powinności edukacji międzykulturowej, kto dąży do ich urzeczywistniania, kto z tej racji ćwiczy się w sprawnościach niezbędnych do uczestniczenia w relacjach międzykulturowych. Co więcej, uznaje się, iż dzięki temu może on stawać się „bogatszym wewnętrznie”. Ten zestaw przekonań, leżących u podstaw edukacji międzykulturowej, współgra z kwestiami sygnalizowanymi w tytule, gdzie mowa o klasycznie rozumianym ćwiczeniu duchowym oraz zwraca się uwagę na „wartości ponadkulturowe", czyli wartości postrzegane jako uniwersalne.

Nawiązuję m.in. do myśli pedagogicznej Tadeusza Kotarbińskiego, łączącego doskonalenie kultury duchowej - wyrażające się m.in. otwartością na wartości i sprawy uniwersalne - z kształtowaniem „ludzi wspólnie rozumnych”. Jako wiodącą kwestię, która może być też przedmiotem ćwiczenia duchowego, będącego formą uprawiania edukacji międzykulturowej, obrano sposoby rozumienia prawdy, dobra i piękna, czyli wartości określanych mianem „ponadkulturowych”, zespolonych z kształtowaniem życia duchowego człowieka. Analizę znaczenia i roli tych wartości usytuowano w interesującym edukację międzykulturową kontekście wielokulturowości i pogranicza, zróżnicowania religijnego i pluralizmu światopoglądowego oraz kompetencji służących komunikacji międzykulturowej. W tym kontekście usytuowane są także - podjęte m.in. za Władysławem Stróżewskim - pytania o rozumienie tych wartości, które uznaje się za jakości przekraczające (transcendujące) ograniczenia danej formacji kulturowej (za wartości transkulturowe). Tak ukierunkowane dociekania mają być przyczynkiem do dalszego 
rozwoju polskiej koncepcji edukacji międzykulturowej. Mogą być odczytane jako przykład współdziałania refleksji pedagogicznej i filozoficznej, jako ich wspólny wkład do edukacji międzykulturowej. Mogą zachęcać do rozwijania refleksji filozoficznej i aksjologicznej nad problematyką podejmowaną przez pedagogikę i edukację międzykulturową.

Słowa kluczowe: edukacja międzykulturowa, ćwiczenie duchowe, kształtowanie kultury duchowej, wartości uniwersalne (ponadkulturowe), wielokulturowe pogranicza

Edukacja międzykulturowa sprzyjać ma upowszechnianiu nowych postaw wobec „innych" [...], wzajemnemu wzbogacaniu kultur, zbliżeniu ludzi i ksztattowaniu wspólnie uznawanych światów wartości [...]. Tadeusz Lewowicki (2001, s. 161)

[Edukacja] ma do spetnienia nie tylko podtrzymywanie wtasnej czy dominujacej tradycji religijnej, ale [...] niesienie wiedzy o innych religiach, [...], uczenie krytycznego podejścia do kwestii religijnych i poszukiwania wartości i spraw, które [...] maja wymiar uniwersalny.

Tadeusz Lewowicki (2013, ss. 25-26)

Komunikowanie międzykulturowe, które jest głównym celem edukacji, jest przekraczaniem granic własnej kultury, wychodzeniem na pogranicza [...], aby stawać się bogatszym wewnętrznie.

Jerzy Nikitorowicz (2001, s. 8)

W programowych wypowiedziach o edukacji międzykulturowej (także w obranych tu za motto) wskazuje się, że zasadnicze cele i powinności edukacji międzykulturowej mocno wiążą się ze sferą wartości i z kształtowaniem kultury duchowej. Przyjmuje się, że do wiodących zadań edukacji międzykulturowej należy poszukiwanie wartości mających wymiar uniwersalny, rozpoznawanie i praktyczne urzeczywistnianie „wspólnie uznawanych światów wartości", kształtowanie postawy rozumnej otwartości na kulturową odmienność, wyrabianie umiejętności komunikowania międzykulturowego i spotkania z Innym. Wymaga to przekraczania granic i kodów własnej kul- 
tury, wychodzenia na wielokulturowe pogranicza zróżnicowania religijnego i pluralizmu światopoglądowego. „Idea pedagogiki i edukacji międzykulturowej - jak ujmuje to Tadeusz Lewowicki ${ }^{1}$ - zakłada wzajemne poznawanie ludzi i kultur różnych społeczności, prowadzi do wrażliwości na Innych i ich kultury, do wzajemnego przejmowania (godnych tego) wzorów życia, do wzajemnego wzbogacenia kultur, kooperacji, przyjaźni [...]" (Lewowicki, 2011, ss. 22-23). Zwraca się przy tym uwagę na proces przemiany, która powinna - także dzięki działaniom pedagogicznym ${ }^{2}$ - zachodzić w osobie przyjmującej za własne cele i powinności edukacji międzykulturowej, dążącej do ich urzeczywistniania i z tej racji ćwiczącej się w sprawnościach niezbędnych do uczestniczenia w relacjach międzykulturowych ${ }^{3}$. Co więcej, uznaje się, iż dzięki takiemu postępowaniu - zalecanemu w edukacji międzykulturowej - osoba angażująca się w wielowymiarowe relacje międzykulturowe może stawać się osobą „bogatszą wewnętrznie”.

1 O rozwoju cieszyńskiej szkoły badań pogranicza i edukacji międzykulturowej, szkoły uformowanej przez Lewowickiego, zob. (Ogrodzka-Mazur, 2014, ss. 25-39); (Ogrodzka-Mazur i Szczurek-Boruta, 2012, ss. 19-40). O poszukiwaniach modelu edukacji międzykulturowej zob. (Lewowicki, 2000, ss. 21-35).

2 O zmianie (m.in. wewnętrznej przemianie), do której powinny prowadzić działania pedagogiczne, także w odniesieniu do osoby pedagoga, pisze Bogusław Śliwerski: „Pedagog [...] powinien być artystą, kimś twórczym [...]. Trzeba umieć wyjść poza stereotyp, poza zadany szablon, obudzić w człowieku «coś», co jest w nim lub w związku z nim, jakieś doświadczenie, wyzwolić w nim inną wrażliwość, dodać coś do bagażu jego przeżyć, wyjść ku drugiemu i podjąć z nim współpracę" (Śliwerski, 2010, s. 139). O współczesnym rozumieniu przemiany duchowej (jako także pojęciu psychologii rozwoju człowieka) zob. (Socha, 2014, ss. 9-22). O duchowości jako wartości i obszarze wspierania ludzkiego rozwoju w ujęciu pedagogiki zob. (Kostkiewicz, 2004, ss. 141-152).

3 „Edukacja międzykulturowa, opowiadając się za wzajemnym wzbogaceniem kultur [...] wnika w istotę kultur, przygotowując do dialogowych interakcji [...]. Dostarcza treningu inności i obcości, umożliwia [...] tworzenie własnej kultury z jednoczesnym nabywaniem postawy tolerancji i uznania wobec innych kultur" (Nikitorowicz, 2001, s. 124). „Edukacja międzykulturowa [...], jako pedagogika spotkania i konfliktu kultur, proponuje paradygmat współistnienia, dialogu [...]" (Szczurek-Boruta, 2007, s. 30). O kształtowaniu międzykulturowej kompetencji komunikacyjnej jako transgresji zob. (Jaskóła i Korporowicz, 2013, ss. 121-138). O współczesnym rozumieniu wielokulturowości zob. (Śliz i Szczepański, 2015, ss. 13-27). Własną próbę socjologicznego i zarazem syntezującego ujęcia problematyki wielokulturowości (niejako stygmatyzującej różne wymiary przestrzeni społecznej) przedstawia Anna Śliz w swej monografii (Śliz, 2017). 
Ten zestaw przekonań, leżących u podstaw idei i praktyki polskiego nurtu edukacji międzykulturowej, zdaje się współgrać z kwestiami sygnalizowanymi w tytule, w którym mowa o ćwiczeniu duchowym, i w dopełniającym go podtytule, w którym zwraca się uwagę na „wartości ponadkulturowe”", czyli wartości postrzegane jako wspólne i uniwersalne.

\section{Edukacja międzykulturowa w perspektywie ćwiczenia duchowego i kształtowania kultury duchowej}

Zaproponowana problematyka ćwiczenia duchowego, kształtowania kultury duchowej i rozumienia „wartości ponadkulturowych” wymaga wstępnych wyjaśnień. Użyte bowiem w tytule kategorie - mające genezę głównie w filozofii, etyce i aksjologii - mogą sprawiać kłopot w intuicyjnym uchwyceniu ich sensu, gdy odnosi się je do edukacji międzykulturowej i zagadnień mieszczących się w kręgu jej zainteresowań. Co to znaczy, że edukację międzykulturową można zasadnie ujmować także jako formę ćwiczenia duchowego? Skąd tak ukierunkowany zamysł dociekań czerpie inspiracje? Co go motywuje i usprawiedliwia? Dlaczego owo ćwiczenie duchowe ma w szczególności dotyczyć - skądinąd kontrowersyjnej - problematyki „wspólnie uznawanych światów wartości” i „wartości ponadkulturowych”, w szczególności zaś prawdy, dobra i piękna? I dlaczego refleksję nad tymi wartościami sytuuje się w potęgującym jeszcze wątpliwości i kontrowersje (jakby je unieważniającym ${ }^{5}$ ) kontekście zróżnicowania religijnego i pluralizmu światopoglądowego ${ }^{6}$ ?

$4 \mathrm{Na}$ „wartości ponadkulturowe” i „błąd naturalistyczny” jako na problemy badawcze dotyczące też edukacji międzykulturowej zwracałem uwagę (idąc za analizami Władysława Stróżewskiego): (Rembierz, 2017a, s. 52).

5 Destrukcję znaczenia wartości postrzega się też jako kryzys i destrukcję relacji międzykulturowych: „[Idee] wielokulturowości przeżywają kryzys [...] liberalizmu, relatywizmu kulturowego i poprawności politycznej, [...] prowadzą [cych] do wykluczania tożsamościowego i marginalizacji [...] imigrantów, ale także obywateli kraju ich przyjmującego. Bezrefleksyjne posługiwanie się kanonem relatywizmu i politycznej poprawności, uznanie wszystkich kultur za równe [...] było reakcją na negatywne zjawiska [...] hegemonii, kolonializmu [...]" (Nikitorowicz, 2014, s. 174). O kryzysie cywilizacyjnym zob. Wielecki, 2016, ss. 45-58. „Diagnoza kryzysu [...] [zachodniego] ładu społecznego, stawia [...] dramatyczne pytania o przyszłość" (Wielecki, 2016, s. 51).

6 O myśleniu religijnym w obliczu pluralizmu i relacji międzykulturowych, zob. (Rembierz, 2014, ss. 17-50). 
Na bliską tradycji ćwiczenia duchowego ideę, że właściwie rozumiana edukacja międzykulturowa „przywraca wiarę w człowieka, w jego moc wewnętrzną i jego wrażliwość na potrzeby INNEGO” i pozwala „stawać się bogatszym wewnętrznie", na bliskie ćwiczeniu duchowemu odwoływanie się w edukacji międzykulturowej do „własnego umysłu i serca, ich mocy twórczej”, do „samodzielnego wyznaczania roli społecznej, własnej akceptacji zasad moralnych, osobistego określania swego życia", wskazuje Jerzy Nikitorowicz, współtwórca polskiej koncepcji edukacji międzykulturowej. W studium Od podmiotowości do międzykulturowości i z powrotem... istotne są kategorie prowadzące w stronę rozumienia edukacji międzykulturowej jako ćwiczenia duchowego, występują założenia uwidaczniające zbieżność koncepcji edukacji międzykulturowej z koncepcją i celami ćwiczenia duchowego:

„Edukacja międzykulturowa promując paradygmat «współistnienia», który zakłada możliwość wzajemnego rozwoju w wyniku [...] procesów wewnętrznych, dialogu, porozumienia, negocjacji, kooperacji, przywraca wiarę w człowieka, w jego moc wewnętrzną i jego wrażliwość na potrzeby INNEGO. «Bycie sobą i u siebie», szacunek i rozumienie siebie oraz bycie «między» nakłada na jednostkę przyjęcie normatywnych funkcji kultury, oparcie się na własnych możliwościach twórczych, wykorzystanie własnego umysłu i serca, ich mocy twórczej. W takiej edukacji wymagania nie są kierowane od instytucji do jednostek, ale od jednostek do instytucji i dotyczą godności i uznania. Godność jest związana z prawem do samodzielnego wyznaczania [...] roli społecznej, własnej akceptacji zasad moralnych, osobistego określania swojego życia. Uznanie [...] jako siła bodźców motywująca, nadająca sens działaniu [...]" (Nikitorowicz, 2001a, s. 17).

Uznając na gruncie edukacji międzykulturowej intensyfikującą się wielokulturowość za stale „narastający proces społeczny”, wykazuje się, jako kwestię wymagającą pilnej uwagi nie tylko ze strony pedagogów, „konieczność wypracowania takich strategii edukacyjnych, które umożliwiałyby kształtowanie odpowiednich kompetencji [...]: z jednej strony poczucia podmiotowości, własnego sprawstwa, wolności i odpowiedzialności, z drugiej wdrażanie do funkcjonowania w układach wielo- i międzykulturowych, kształtowanie solidarności [...] oraz integracji wobec ogólnoludzkich i ponadczasowych wartości" (Nikitorowicz, 2001a, s. 17). Zarysowuje się tu stawiający wysokie wymagania program aksjologiczny edukacji międzykulturowej, która dąży do kształtowania kompetencji i postaw właściwych dla relacji międzykulturowych w wymiarze życia jednostkowego i życia społecznego. Ta wizja edukacji 
odrzuca roszczenia kolektywizmu i wiarę w omnipotencję instytucji (wymagania idące „od instytucji do jednostek”), natomiast promuje podmiotową godność i sprawczość jednostek ${ }^{7}$.

Postulowane i urzeczywistniane na gruncie edukacji międzykulturowej kształtowanie sprawności (kompetencji międzykulturowych) oraz otwarcie na sprawę „ogólnoludzkich i ponadczasowych wartości” bliskie jest rozumienia ćwiczenia duchowego, które ma przebiegać w sytuacji relacji (także napięć, komplikacji i nieporozumień) międzykulturowych jako procesie komunikacji i wymiany wartości: „Tożsamość kształtowana jest wówczas, gdy jednostka w procesie komunikowania potrafi spojrzeć na siebie oczami innych i właśnie w ten sposób stwarza sobie obraz samej siebie. Wyizolowana jednostka nie jest w stanie dojść do takiej samorefleksji" (Nikitorowicz, 2001a, s. 21) ${ }^{8}$. To właśnie aksjologicznie nasycona istotnymi wartościami relacja z innym/innymi, której uczestnicy potrafią „spojrzeć na siebie oczami innych", potrafią odczytać, ocenić i przeformułować własny świat wartości w kontekście innych światów wartości, ma być sytuacją wydatnie sprzyjającą kształtowaniu własnej kultury duchowej ${ }^{9}$. Na potrzebę kształtowania zdol-

7 O znaczeniu sporu o koncepcję społeczeństwa i wartość jednostki dla myśli pedagogicznej zob.: (Rembierz, 2018, ss. 59-90). O godności jako wartości społeczno-moralnej i kwestii pedagogicznej zob. (Mariański, 2016).

8 „[Problemem wielokulturowości] jest wzajemne poznanie się w kontekście postrzegania siebie. [...] [Powinny] nas interesować różne skutki współwystępowania i wzajemnego postrzegania się" (Nikitorowicz, 2011, s. 24). Na możliwe związki między różnorodnością kulturową a zagrożeniem rozpadu tożsamości, uwagę zwraca Krzysztof Wielecki (2014, ss. 41-52). „[...] wielokulturowość może się też mylić z anomią. Taka quasi wielokulturowość może być stanem niedojrzałości kultury [...]. [...] Wielokulturowość jest bardzo wymagająca. Wytrzymują ją i potrafią z pożytkiem wykorzystać ludzie dojrzali, o pełnej, dojrzałej tożsamości [...]. Jej warunkiem jest zatem dojrzałość kultur składających się na tę wielość. [...] Człowiek może tworzyć swoją tożsamość i osobowość [...] [w warunkach], bodaj minimalnej, koherencji środowiska kulturowego. Zagrożenie nie bierze się bezpośrednio z różnorodności, ale z braku mikrokultury, która pozwala ustosunkować się do tej wielości i odnaleźć się w niej oraz skonstruować [...] horyzonty odniesienia. Głównym czynnikiem znoszącym takie mikrokultury jest kultura masowa - zabójcza dla istnienia tożsamości kulturowych" (Wielecki, 2014, s. 51).

9 „Aby kształtować kompetencje międzykulturowe, potrzebna jest wiedza związana z atrybutami kryterialnymi własnej kultury, zwłaszcza tymi, które stanowią łączniki/ pomosty między kulturami Innych. [...] istotne jest to w sferze religijnej. Niestety, [...] w niedostatecznym stopniu wykorzystuje [się] możliwość [...] wychowania międzykul- 
ności pozwalających „spojrzeć na siebie oczami innych” kładł nacisk w Etyce solidarności Józef Tischner (1931-2000):

„Ani ja, ani ty nie jesteśmy w stanie poznać prawdy o sobie, jeśli pozostaniemy w oddaleniu od siebie, zamknięci w ścianach naszych lęków, lecz musimy spojrzeć na siebie niejako z zewnątrz, ja twoimi, a ty moimi oczami, musimy porównać w rozmowie nasze widoki [...]. Dopóki ja patrzę na siebie wyłącznie swoimi oczami - znam część prawdy. [...] Pełna prawda jest owocem wspólnych doświadczeń, twoich o mnie, a moich o tobie. Wspólne poglądy są owocem przemiany punktów widzenia" (Tischner, 1981, ss. 15-16).

Kształtowanie takich przekonań i umiejętności, aby dzięki nim dokonywała się w relacjach międzyludzkich dialogiczna „przemiana punktów widzenia” jest także jednym z wiodących postulatów ćwiczeń duchowych i zadań edukacji międzykulturowej.

Formując kategorię międzykulturowości, intensywnie nasyca się ją na gruncie edukacji międzykulturowej przede wszystkim takimi treściami egzystencjalnymi i aksjologicznymi, aby wyraźnie wskazywała na dynamikę wzajemności w relacjach między różnymi światami wartości, w których odnajduje się także to, co wspólne, na dynamikę wzajemnego „uczenia się” w kształtowaniu kultury duchowej otwartej na to, co odmienne i na to, co wspólne w różnych światach wartości, na rozwijające kulturę duchową ćwiczenie się w umiejętności uczestnictwa w relacjach między odmiennymi kulturami i różniącymi się światami wartości. „Perspektywa międzykulturowości - jak stwierdza Leszek Korporowicz - lepiej oddaje [...] transkulturowy charakter procesów wzajemnego uczenia się, włączenie w obszar własnych standardów i wartości kulturowych wartości innych grup w sposób daleki od wymuszania i asymilacji” (Korporowicz, 1997, s. 69) ${ }^{10}$. Aby właściwie rozumieć i odpowiednio kształtować relacje międzykulturowe, niezbędne jest

turowego w przestrzeni kulturowej wygenerowanej przez religię. [...] instytucje religijne w pracy formacyjnej [...] pomijają konteksty [...] związków z innymi religiami i wyznaniami” (Sobecki, 2014, s. 118). „[...] edukacja prowadząca do poznania, zrozumienia i nawiązania dialogu z ludźmi innej religii czy światopoglądu - to szansa [...] kształtowania otwartej tożsamości religijnej młodych ludzi. To również edukacja stymulująca proces tworzenia bardziej otwartego [...] społeczeństwa" (Różańska, 2015, s. 183).

10 „[...] międzykulturowość jest rozumiana jako nowy model działalności wychowawczej [...] wyznaczający nowe podstawy w relacjach międzyludzkich, co wymaga swoistej transformacji naszej wiedzy antropologicznej związanej z rozumieniem podmiotu, komunikowania i sposobów myślenia" (Nowak, 2012, s. 565). 
ukierunkowanie na sytuację „wzajemnego uczenia się”. Bez chęci wzajemnego uczenia się i bez rozwijania umiejętności służących wzajemnemu uczeniu się - jako ciągłemu procesowi - nie urzeczywistni się na dłuższą metę pożądanych (dobrych) relacji między przedstawicielami różnych kultur ${ }^{11}$.

Warto więc odczytać i rozwijać zasygnalizowane aspekty edukacji międzykulturowej w kontekście faktu, że dyskurs współczesnej humanistyki odzyskuje - nieco zapomniane i bywało, że kojarzone zbyt wąsko, bo tylko religijnie - klasyczne grecko-rzymskie rozumienie ćwiczenia duchowego. $\mathrm{Na}$ nowo odkrywa się znaczenie źródłowo sokratejskiego, jak też platońskiego, perypatetyckiego, stoickiego, epikurejskiego, ale i sceptycznego, ćwiczenia duchowego. Pojmowano je bowiem w wymienionych nurtach i doktrynach jako wychowanie, samowychowanie i przekształcanie człowieka, jako formowanie jego sprawności duchowych i intelektualnych, zwłaszcza dzięki będącej "sztuką życia”, pełniącej funkcje „pajdetyczne” i terapeutyczne filozofii ${ }^{12}$. Do przywrócenia i promowania ćwiczenia duchowego w dyskursie humanistyki walnie przyczynili się swymi badaniami i rozprawami Pierre Hadot (1922-2010) i Juliusz Domański. Na poznawcze walory ich dokonań badawczych i ich praktyczny wymiar wskazywali m.in. Barbara Skarga (1919-2009) ${ }^{13}$, Michał Heller ${ }^{14}$ i Krzysztof Stachewicz ${ }^{15}$.

11 Zob. (Korporowicz, 2015, ss. 18-34).

12 Zob. (Rarot, 2015, ss. 68-78). O filozoficznej trosce o duszę jako wychowaniu, zob. (Dancák, 2011, ss. 211-220).

13 Zob. (Skarga, 1999, ss. 325-327).

14 Zob. (Heller, 2006, ss. 132-140). „W trakcie medytacji lub lektury [filozoficznej] nie da się [...] unikać refleksji nad sobą. Filozofia i życie muszą spotkać się w tym, kto filozofuje. Filozofia może stać się sposobem na życie pod warunkiem takiego spotkania. [...] przemyślenia filozoficzne powinny wzbogacać nasze życie wewnętrzne, ale filozofia nie spełnia swego zadania jako »sposobu na życie«, jeśli nie dostarcza nam trzeźwych kryteriów do oceny swojego postępowania i [...] wskazówek, jak należy postępować w przyszłości. Być może [...] [kogoś zaskoczy], że rachunek sumienia [...] chrześcijanie [przejęli] od filozofów greckich” (Heller, 2006, s. 137).

15 Zob. (Stachewicz, 2013, ss. 219-234). „Już w [...] pierwszym okresie [...] [pojawia się] rozumienie filozofii chrześcijańskiej jako sposobu życia. Nawiązywało to do [...] starożytnych myślicieli pogańskich, dla których moment ascetyczny, egzystencjalny rozważań filozoficznych był nierzadko pierwszoplanowy. Wskazują na to w swych znakomitych opracowaniach Pierre Hadot czy Juliusz Domański widząc w starożytnym filozofowaniu sposób kształtowania życia, ćwiczenia duchowe, uczenie się sztuki życia. Przyjęcie określonej filozofii oznaczało [...] u Platona «nawrócenie», zmianę sposobu życia” (Stachewicz, 2013, s. 220). 
Rozpatrując idee i programy starożytnych filozofów, Hadot eksponuje jako nadrzędne praktyczne i autoedukacyjne wymiary ich filozofii. Filozofia w dużej mierze jest rozumiana i uprawiana jako ćwiczenie duchowe, jej koncepcje są przedmiotem ćwiczeń intelektualnych, są wprzęgnięte w praktykę życia kontemplacyjnego jako ćwiczenia duchowego lub (stoicyzm, epikureizm) są podporządkowane praktyce duchowej kształtującej codzienne postawy.

Jednym ze źródeł koncepcji i praktyki ćwiczenia duchowego jest - praktykowany w pedagogice ${ }^{16}$ - dialog sokratyczny. Stanowi on „uprawiane wspólnie ćwiczenie duchowe, zachęcające do wewnętrznego ćwiczenia duchowego, do badania świadomości, do baczenia na siebie, [...] do sławnego «poznaj samego siebie»" (Hadot, 1992, s. 29). W sokratejskiej dydaktyce - jako sztuce kształtowania duchowego, intelektualnego i moralnego - nie idzie o wąski dydaktyzm, aby skutecznie przyswajać wiedzę uznaną za przydatną (np. dla rozwoju duchowego, intelektualnego lub moralnego w wymiarze indywidualnym lub społecznym), nie chodzi o powierzchownie pojmowane „uczenie” i „nauczanie”, ale o rozumienie własnej wiedzy, jej granic i słabości (zwłaszcza tej wiedzy, która osobiście nas angażuje i wydaje się wiedzą dość pewną, która dla innych powinna być też zrozumiała i oczywista). „W dialogu «sokratycznym» rozmówca Sokratesa niczego się nie uczy i Sokrates nie rości sobie pretensji do nauczenia go czegokolwiek: powtarza zresztą temu, kto go chce słuchać, że jedyną rzeczą, którą wie, jest, że nic nie wie. Ale jak bąk niestrudzony Sokrates dręczy swoich rozmówców zapytaniami, które ich samych pod znakiem zapytania stawiają, które ich zmuszają do zwrócenia uwagi na siebie, do dbania o siebie samych" (Hadot, 1992, s. 28). Wypracowywanie wiedzy o własnej niewiedzy to - uciążliwe, bo idące pod prąd nawyków uczenie się niewiedzy, prowadzi do podejmowania pytań, które mnie stawiają „pod znakiem zapytania”. Jest to doświadczenie podobne do odkrywania w relacjach międzykulturowych własnej niewiedzy o innych i o samym sobie, do znalezienia się w sytuacji „pod znakiem zapytania”, gdy moje oczywistości i sposoby rozumienia nie są dla innych oczywistymi ${ }^{17}$. Sokratejski dialog

16 Zob. (Gara, 2010, ss. 137-148). „Człowiek w swej mowie zagaduje drugiego człowieka. Zagadnięcie to jest [...] właściwością istoty ludzkiej i zasadza się na [...] uznaniu samodzielnej inności drugiego człowieka. Prawdziwa rozmowa odzwierciedla [...] bezpośredniość kontaktu i [...] jest «szansą uczłowieczenia». [...] [Rozmowa] jest aktem konstytuującym przestrzeń międzypodmiotowej relacji i jest rezygnacją z pozycyjności zdystansowanego obserwatora [...]" (Gara, 2010, s. 147). O pedagogice dialogu zob. (Milerski, 2008, ss. 29-42).

17 „Destrukturyzacja pozwala pedagogowi międzykulturowemu na skierowanie 
przedstawia się nie tylko jako ćwiczenie duchowe przydatne w relacjach międzykulturowych, ale same te relacje jako sposobność do praktyki ćwiczenia duchowego powinny przybrać postać dialogu, w którym docieka się sensu wartości i właściwego w danej sytuacji sposobu uczestnictwa w zróżnicowanym świecie wartości, aby je urzeczywistniać.

Sokratejskie źródła ćwiczenia duchowego to także - podszyta ironią i dystansem wobec własnej osoby - wypowiedź Sokratesa: „Ja nie jestem w stanie, jak napis w Delfach powiada, poznać samego siebie. Więc mi się to śmieszne wydaje, kiedy siebie jeszcze nie znam, bawić się w jakieś nie swoje, niesamowite dociekania. Siebie samego badam, czy ja sam nie jestem bydle bardziej zawiłe i zakręcone, i nadęte niż Tyfon, czy też prostsze i bardziej łaskawe, które z natury ma w sobie coś boskiego i coś niskiego" (Platon, Fajdros 229 e $4-230$ a 6). Inny - nie tylko odmienny, ale w jakiejś mierze obcy i nieprzystający do nas - uobecnia się niejako w każdym z nas. Tym kimś innym - także dla samego siebie - staje się każdy z nas, gdy „rzucony” jest w różne, odmienne zewnętrzne sytuacje i zróżnicowane wewnętrzne stany ducha, z którymi przychodzi się zmagać i zarazem zmagać z samym sobą o to, kim się w tej dynamicznie „innej” sytuacji faktycznie jest i o to, kim się powinno być. Dlatego występują istotne trudności, aby w zadowalającym stopniu, w miarę wyczerpująco i pewnie, poznać siebie. Doświadczając inności, która jest w nas, doświadcza się rozdwojenia lub zwielokrotnienia stanów sobie przeciwstawnych i zdawałoby się, że wykluczających się w jednym podmiocie: „czy ja nie jestem bydle bardziej zawiłe i nadęte niż Tyfon, czy też prostsze i bardziej łaskawe, które ma coś boskiego i coś niskiego". W zetknięciu z wielością odmienności, które są nie tylko czymś, co nadchodzi z oddali, ale są czymś, co człowiek nosi w sobie, powstaje wezwanie do ćwiczenia duchowego, aby lepiej poznać siebie w obliczu - trudnej do pojęcia - inności, będącej też - i to na wiele sposobów - częścią nas samych.

Ćwiczenia duchowe w filozoficznych szkołach greckich i rzymskich miały funkcje wychowawcze, miały służyć przekształcaniu postrzegania świata i funkcjonowania w świecie, miały wiązać się z tym, co uniwersalne. Pod tym względem można upatrywać podobieństwo do wychowawczych programów i działań edukacji międzykulturowej. Miały między innymi prowadzić „do zapanowania nad mową wewnętrzną, w celu uczynienia jej spójną, uładzenia jej" (Hadot, 1992, s. 20). Aby mowa wewnętrzna, różnicująca ludzi i ich

spojrzenia ku własnej kulturze, w celu dokonania demontażu założeń koncepcyjnych i paradygmatycznych, które w sumie tylko wzmacniają redukcjonistyczne ujęcie kultury przez ludzi Zachodu, oparte na poczuciu wyższości” (Nowak, 2012, s. 573). 
zindywidualizowaną kulturę duchową, nie była generatorem radykalnych podziałów i nie wzmagała antagonizmu.

Ćwiczenia dialektyczne (zwłaszcza wedle Platona) powinny skutkować poddaniem się Logosowi, powinny być ćwiczeniem czystej myśli i prowadzić do wewnętrznej przemiany. Chodzi o takie odwrócenie się duszy od spraw materialnych (generujących m.in. iluzje), które przesłaniają ogląd rzeczywistości i dzielą ludzi (mających odmienne wyobrażenia, żywiących złudne przekonania), aby nastąpiło jej ukierunkowanie w stronę Dobra, które może stanowić wspólną i nieantagonistyczną rzeczywistość wszystkich ludzi. Tak zarysowany koncept uniwersalizmu duchowego, intelektualnego i moralnego dążenia w stronę Dobra, jako wartości wspólnej i niedającej się nikomu na wyłączność przypisać (ulec partykularyzacji, zawłaszczeniu), daje też asumpt dla edukacji międzykulturowej do kształtowania przeświadczeń aksjologicznych o „wspólnie uznawanych światach wartości”, o możliwości i potrzebie „integracji wokół ogólnoludzkich i ponadczasowych wartości”, oraz do rozeznawania statusu „wartości ponadkulturowych".

Dzięki ćwiczeniom duchowym podejmująca je osoba w pewnej mierze przekracza siebie i wyznaczoną przez jej życiowe przypadki granicę oddzielającą ją od - aksjologicznie pojętej - „Całości”. Wkracza ona w uniwersum wartości, które dotąd było dla niej przesłonięte, i uczy się go jakby na nowo. Przezwycięża „wyolbrzymione obawy” wobec tego, co inne i nieznane w tym trudnym do ogarnięcia i jednoznacznego określenia uniwersum. Wiąże się to „z gruntownym przekształceniem sposobu postrzegania i sposobu bycia jednostki. Realizacja tego przekształcenia - oto cel ćwiczeń duchowych" (Hadot, 1992, s. 15$)^{18}$. Takie podejście do ćwiczeń duchowych może być odczytane, jakby było zaczerpnięte z programowych tez edukacji międzykulturowej lub spójnie dopełniało te tezy.

W relacjach międzykulturowych i w dokonującej się w nich wymianie wartości niezbędne jest przejście od wyłącznie emocjonalnego, opartego na własnych namiętnościach i interesach, przywiązania do swych wartości i ich absolutyzowania z tego powodu, iż są własne, do prób całościowego rozeznania (całościowego widzenia) zróżnicowanego świata wartości czy też

18 „Wiedza naukowa była obiektywna i matematyczna, podczas gdy świadomość kosmiczna stanowiła wynik duchowego ćwiczenia polegającego na uświadamianiu sobie miejsca jednostkowego istnienia w wielkim biegu kosmosu, w wymiarze Całości: «toti se inserens mundo» («zanurzając się w całość świata») - pisał Seneka. Ćwiczenie to nie umieszczało się w absolutnej przestrzeni ścisłej wiedzy, ale w przeżytym doświadczeniu konkretnego podmiotu, żyjącego i postrzegającego" (Hadot, 1992, s. 231). 
odmiennych światów wartości. Podobnie ujmowane są funkcje ćwiczenia duchowego: „Przechodzi się od «ludzkiego» widzenia rzeczywistości, takiego, w którym wartości zależą od namiętności, do widzenia «naturalnego» rzeczy, które stawia każde zdarzenie w wymiarze natury powszechnej. Ta zmiana optyki [...] [wymaga] przekształcenia wewnętrznego" (Hadot, 1992, s. 15). W relacjach międzykulturowych niezbędne jest tego rodzaju kształtowanie kultury duchowej uczestników tych relacji.

W epikurejskim ćwiczeniu duchowym istotną rolę pełni wyobrażenie wyjścia poza dotychczasowe granice i zamknięte wizje rzeczywistości. „Kontemplacja świata fizycznego i wyobrażenie nieskończoności [...] powodują całkowitą zmianę sposobu widzenia rzeczy (zamknięty wszechświat rozszerza się w nieskończoność) i przyjemność duchową «[...]: Otwierają się i padają mury świata, widzę, jak w próżni wszechświata wytwarzają się rzeczy [...]. [Natura], tak jawnie się odkrywająca, pozbawiona została jakiejkolwiek zasłony» (Lukrecjusz, De rerum natura, III)" (Hadot, 1992, s. 25). Tu odsłania się uniwersalistyczna wizja doświadczania wspólnego świata, która może stanowić okazję do ćwiczenia wyobraźni i inspirację do formułowania koncepcji otwartości w relacjach międzykulturowych.

Ćwiczenia duchowe kształtowały relacje przyjacielskie między ćwiczącymi, a zarazem ćwiczenia wymagały tych relacji, bo bez nich pozostawały ułomne. Dlatego skłaniano się do przekonania, że „nade wszystko sama przyjaźń jest niejako ćwiczeniem duchowym w pełnym tego słowa znaczeniu" (Hadot, 1992, s. 26). Jeśli w pedagogice i edukacji międzykulturowej podnosi się kwestię wartości przyjaźni ${ }^{19}$, to nawiązanie do tradycji ćwiczenia duchowego może pozwolić lepiej wyeksplikować znaczenie tej wartości w relacjach międzykulturowych.

Ćwiczenia duchowe obejmowały kształtowanie podejścia „do siebie, do kosmosu, do innych ludzi" (Hadot, 1992, s. 232). Eksponując walory tego sposobu kształtowania podejścia do innych ludzi, Hadot dopowiada, że także w tej sprawie „antyczne tradycje filozoficzne są pouczające”. Polemizuje przy tym z fałszywym przekonaniem, że filozofia „ukazywała drogi ucieczki, wycofania się w głąb siebie: u platoników ucieczki w niebo Idei, u epikurejczyków

19 O przyjaźni zob. (Ogrodzka-Mazur, 2010, ss. 427-430). „Nawiązywanie przyjaźni warunkuje doświadczanie innych wartości moralnych i poznawczych, a przede wszystkim wartości miłości, dobra i prawdy. Przyjaźń [....] [wymaga] długiego okresu czasu służącego wzajemnemu poznawaniu się, [...] można obdarzać przyjaźnią wiele osób [...]. [Przyjaźń jest] odpowiedzią serca na wartość drugiej osoby" (Ogrodzka-Mazur, 2010, s. 430). O normatywności pojęcia przyjaźni i jego miejscu w teoriach etycznych zob. (Szutta, 2010, ss. 125-151). 
- w odrzucenie polityki, u stoików w poddanie się Losowi”. Zaangażowanie społeczne filozofii nastwionej na ćwiczenie duchowe było wyraźne, gdyż „zakłada [ona] wspólny wysiłek, wspólnotę poszukiwań, wzajemnej pomocy, duchowego wsparcia. [...] [Filozofowie] nigdy nie zrezygnowali z oddziaływania na państwo, z przekształcania społeczeństwa, ze służby współobywatelom [...]" (Hadot, 1992, s. 232).

Poszukiwanie i rozeznawanie w ćwiczeniu duchowym „Rozumu wspólnego istotom ludzkim" prowadzi do zaangażowania społecznego i w ten sposób kształtuje się dojrzała „troska o życie w służbie wspólnoty ludzi, o działanie wedle sprawiedliwości”. Dzięki praktyce ćwiczenia duchowego, angażując się w sprawy społeczne, dąży się do „trzymania się na poziomie racjonalności, niedopuszczenia do zaślepienia przez namiętności polityczne, gniew, urazę, uprzedzenia" (Hadot, 1992, s. 232). Tym samym daje się szansę przezwyciężenia, powodowanych urazami i uprzedzeniami, spetryfikowanych antagonizmów, szansę nowego początku. Takie nastawienie jest bliskie dążeniom edukacji międzykulturowej.

Na potrzebę uwzględnienia różnych wymiarów kultury duchowej i zdecydowanego przewartościowania w dominujących "zachodnioeuropejskich" („atlantyckich”) koncepcjach celów i sposobów działań pedagogicznych zwraca uwagę Stefan Swieżawski (1907-2004) ${ }^{20}$, rozpatrując niedostatki tych koncepcji w kontekście relacji i wartości międzykulturowych, a zarazem nawiązując do tradycji klasycznie rozumianego ćwiczenia duchowego:

„Jest tu potrzebna [...] zmiana orientacji pedagogicznej i to [...] od wychowania w rodzinach. Jako pierwsze [...]: zwrócenie uwagi na rewaloryzację «wieku filozoficznego» [...] 4-5 lat, kiedy dziecko stawia [...] filozoficzne pytania, a wychowawcy muszą traktować je poważnie. Druga rzecz, to przyjęcie wzorów z Dalekiego Wschodu: w wychowaniu powinno być [...] więcej ciszy, skupienia, uczenia się kontemplacji [...] (w Polsce mamy bardzo słabą tradycję kontemplacyjną). Niebezpieczeństwem [...] programów nauczania jest przewaga nauk fizyko-matematycznych i przyrodniczych, $\mathrm{z}$ równoczesnym zanikiem humanistyki, [...] języków klasycznych. Dzieci hinduskie powinny przecież znać sanskryt, a Europejczycy łacinę. W wychowaniu trzeba zrobić wszystko, aby mogła się w człowieku rozwijać mądrość" (Swieżawski, 1992, s. 70).

W kontekście relacji międzykulturowych wyeksponowane zostają - częstokroć zaniedbywane lub pomijane - egzystencjalne i edukacyjne wartości

20 O myśli pedagogicznej Swieżawskiego, zob. (Rembierz, 2016b, ss. 135-174). 
„ciszy, skupienia, uczenia się kontemplacji”, które mają służyć kształtowaniu kultury duchowej i rozwijaniu mądrości jako jednej z ludzkich sprawności otwierających na dostrzeganie wartości uniwersalnych.

O możliwości praktykowania w różnych sytuacjach ćwiczenia duchowego $^{21}$, które otwiera na doświadczenie relacji i wartości międzykulturowych, na wymianę i przyswajanie tych wartości, zaświadcza wiersz Jarmark Jagielloński ks. Alfreda Marka Wierzbickiego (2018, s. 12). Podmiot liryczny $\mathrm{w}$ autobiograficznej narracji zdaje sprawę z tego, co wydarza się w sferze jego kultury duchowej, gdy przechadza się po lubelskim Jarmarku Jagiellońskim² ${ }^{22}$, będącym również przestrzenią relacji i wartości międzykulturowych:

„Hafty tkaniny świątki wiklina

rumiane dziewczyny na szkle

zapach wosku miodu i gryczanej kaszy

lirnik w zaułku blask i dźwięk dzwonków

Znalazłem coś dla siebie

- kolorowa misa od Tatarki z Krymu

czeka na gości z bliska i daleka".

21 Rozpatrując kwestię ćwiczenia duchowego w kontekście doświadczenia relacji i wartości międzykulturowych, należy też zwrócić uwagę na nurty określane jako nowa duchowość i na dotyczące ich badania; zob. (Mariański, 2013). „[...] o ile religia jest związana z duchowością, [...], to nie każda duchowość musi być religijna. Coraz więcej ludzi realizuje swoje potrzeby duchowe poza sferą religii, a nawet i niekiedy poza sferą sacrum" (Mariański, 2013, s. 154). Zob. (Pasek, 2010, ss. 56-65); (Kasperek, 2012); (Pasek, 2013); (Baniak, 2013, ss. 13-37); Trzcińska, 2013); (Mariański, 2015, ss. 22-45); (Chmielewski, 2017, ss. 159-179). „Rozwój nowych form religijności i duchowości prowadzi do zacierania granic między tym co religijne i niereligijne. [...] tendencja ku duchowości ma wiele wymiarów [...]. Sprzyja temu [...] pluralizm społeczno-kulturowy i indywidualizm strukturalny (Mariański, 2015, s. 30). „Proponujemy duchowość uznać za stałą, uniwersalną cechę kulturotwórczej postawy człowieka. [...] określa ona szersze niż tylko [...] w ramach religii dążenia człowieka do samorozwoju i doskonalenia się. Określa - paradoksalnie - biologiczną potrzebę zmiany [...], wyniesienia siebie, swojego materialnego [...] ciała ku innemu wymiarowi (różnie rozumianemu), przekroczenia doczesnego „tu i teraz” [...]. Dążenia te [...] mogą się sytuować w różnych dziedzinach kultury [...]. Ten rodzaj „wiecznej tęsknoty” i [...] stałego „napięcia” istniejącego w człowieku jest, być może, stałą i uniwersalną cechą ludzką, zapewne w dużej mierze kulturową, przekazywaną międzypokoleniowo" (Skowronek i Pasek, 2013, s. 8).

22 O Jarmarku Jagiellońskim i upowszechnianiu dziedzictwa kulturowego (Kraczoń, 2014, ss. 143-153). 
Okazją do pogłębionego poetycką refleksyjnością ćwiczenia duchowego jest Jarmark Jagielloński, na którym odkryciem „czegoś dla siebie” jest misa pochodząca z daleka „od Tatarki z Krymu”. Misa staje się przedmiotem niosącym z sobą określone wartości i sytuacje nasycone tymi wartościami, współtworzy ona przestrzeń spotkania również - a może: przede wszystkim - w domu, gdyż „czeka na gości z bliska i daleka”. Staje się ona okazją do ćwiczenia duchowego otwierającego na doświadczenie relacji i wartości międzykulturowych.

\section{Pedagogika wobec zadania doskonalenia kultury duchowej „ludzi wspólnie rozumnych” i „upierwszorzędnienia wartości uniwersalnych"}

Intelektualny impuls i zarazem argument z polskiej tradycji myśli pedagogicznej, aby zaproponować interpretację edukacji międzykulturowej jako również pewnego rodzaju ćwiczenia duchowego, ćwiczenia dzisiaj szczególnie przydatnego $\mathrm{w}$ rozumieniu i kształtowaniu odpowiednich postaw $\mathrm{w}$ relacjach międzykulturowych, pochodzi z metapedagogicznych przemyśleń Tadeusza Kotarbińskiego (1886-1981)23. To może brzmieć zaskakująco, gdyż jego postać i dorobek nie tyle kojarzy się ze sferą duchowości, kulturą duchową i kształtowaniem ludzkiego ducha, co z wypracowanym przez niego programem reizmu (ontologicznego i semantycznego), jak też z agnostycyzmem $\mathrm{i}$ ateizmem, a nawet $\mathrm{z}$ interpretowaniem jego przekonań jako materializmu. A jednak, co jest też wyrazem szerzej pojętego międzykulturowego pogranicza i pluralizmu idei, warto przypomnieć, że to właśnie Kotarbiński w programowym swym tekście Perspektywy myśli pedagogicznej (1970) dawał wyraz przekonaniu o zadaniach pedagogiki w kształtowaniu kultury duchowej.

Kształcenie i wychowanie są - jak stwierdza Kotarbiński - formami „doskonalenia człowieka, urabiania jego kultury”, a pedagogika „staje się kunsztem czynienia ludzi coraz bardziej kulturalnymi” (Kotarbiński, 1970, s. 5) ${ }^{24}$. Dlatego powinna „wyrobić sobie własną niejako filozofię kultury, jako część własnego kunsztu, i nikt jej w tym nie zastąpi”. To jest jedno z ważnych zadań teoretycznych pedagogiki, gdyż występują różne (i nieprzystające do powinności pedagogiki) sposoby pojmowania kultury. Aby uwyraźnić właściwe pedagogice rozumienie kultury duchowej, przeciwstawia się je dominującemu

\footnotetext{
23 O myśli pedagogicznej Kotarbińskiego zob. (Rembierz, 2007, ss. 341-354).

24 Kolejne cytaty pochodzą też z tej strony: (Kotarbiński, 1970, s. 5).
} 
ujęciu kultury w socjologii: „Czego bowiem ludzie nie nazywają kulturą i jak rozmaicie rozumieją to słowo, posiłkując się nim w różnych naukach! Socjologowie dbają o to, by z własnych pojęć usunąć wszelkie wartościowanie emocjonalne, gdy pedagog, prawiąc o kulturze duchowej człowieka wdaje się właśnie z konieczności w sam rdzeń takich ocen”. Wymagania wynikające z sytuacji działań pedagogicznych, sprawiają, iż również promowane w urzędach i mediach „ograniczone, marginesowo-kosmetyczne rozumienie «kultury» jemu [pedagogowi] nie wystarcza". Wspierając pedagogikę w wypracowaniu elementów własnej filozofii kultury, Kotarbiński poddaje pod dyskusję (niezbędne pedagogice) rozumienie kultury duchowej jako środowiska doskonalenia się człowieka: „Człowiek doskonali tworzywo otaczające i kulturą jest ogół udanych wyników jego działań. Ale człowiek dzięki tej działalności urabia pośrednio sam siebie, wzmaga własną wiedzę i wprawę, sam jest przedmiotem, tworzywem działań bezpośrednio na niego skierowanych, pośrednio zaś tych działań które go doskonalą. I otóż pedagogowi potrzebne jest pojęcie kultury tak ogólnie postawione, pojęcie kultury jako ogółu udanych wyników działań ludzkich, a w szczególności pojęcie kultury duchowej człowieka jako ogółu udoskonaleń jego psychiki" (psychika nie jest tu zawężona do obszaru penetracji współczesnej psychologii i jej konstruktów, ale tradycyjnie ujęta jako sfera ludzkiej psyche).

Dynamicznie i perfekcjonistycznie rozumiana kultura duchowa człowieka ściśle wiąże się z odkrywaniem i urzeczywistnianiem przez niego różnorodnych (acz pozytywnych) wartości: „Atoli wszelkie doskonalenie zakłada kierunkowość zmian w stosunku do jakichś wartości”. Rozwijając dalej w swym wywodzie perspektywy myśli pedagogicznej, Kotarbiński zwraca baczną uwagę na procesy postępującej globalizacji, wymuszanej też przez technikę ${ }^{25}$, a także jakby postuluje i zapowiada powstanie edukacji międzykulturowej:

„Trzeba tedy wychowywać ludzi oddanych sprawie racjonalnej organizacji działań ogółu mieszkańców naszej planety, ludzi, w których motywacji ta troska zajmowałaby miejsce naczelne. Nie trzeba w tym celu wyrzekać się upodobań lokalnych i cząstkowych, można nawet pielę-

25 Kotarbiński opisuje procesy dziś nazywane globalizacją: „tendencje [...] przekształcani[a] się ludności globu ziemskiego z plątawiska skłóconych gromad cząstkowych w całość organiczną. W miarę rozkwitu nauki, a pośrednio techniki, narasta sytuacja przymusowa, gdyż to, co się dzieje [...] w którymkolwiek zamieszkanym miejscu Ziemi, zależy coraz bardziej od tego, co się dzieje w innych [...] miejscach Ziemi [...]. Wyniki tych zależności wymagają uzgodnienia, [...] jego brak doprowadz[i] do chaosu [...]" (Kotarbiński, 1970, s. 5). 
gnować folklory z sentymentem; ale trzeba upierwszorzędnić wartości uniwersalne, na przykład wspólne wzmaganie się z czynnikami chorobotwórczymi, z widmem głodu, z deformowaniem otoczenia przez zwały bezużytecznych odpadów, z gospodarką rabunkową, z ciemnotą elementarną" (Kotarbiński, 1970, s. 6).

Uwydatniając doniosłość postulatu „upierwszorzędnienia wartości uniwersalnych" w wychowaniu, Kotarbiński precyzuje rysujące się perspektywy - szczególnie bliskiej jego etycznym przekonaniom - edukacji międzykulturowej: „Ale naczelność uniwersalistycznej motywacji emocjonalnej nie wystarcza. Aby wprowadzić w życie jej nabrzmiałe postulaty, potrzebna jest mądrość, która znajdzie drogi wyjścia z kłótni. Na szczęście rozum zgodny z postępami nauk wchodzi w skład dóbr powszechnych. Więc wychowywać, kształcić ludzi na ludzi wspólnie rozumnych" (Kotarbiński, 1970, s. 6) ${ }^{26}$. Łączy się tu doskonalenie kultury duchowej - wyrażające się m.in. otwartością na wartości uniwersalne - z kształtowaniem postaw i przekonań „ludzi wspólnie rozumnych", czyli formacji takich ludzi, którzy nie dysponują tylko służącym ich wąsko pojętym interesom rozumem instrumentalnym, ale dzięki wspólnej rozumności i zespolonej z nią wrażliwości aksjologicznej są wspólnie otwarci na mądrość i na formowane dzięki niej trafne zalecenia praktyczne.

Nawiązanie do myśli metapedagogicznej Kotarbińskiego, która ukazuje powinność doskonalenia kultury duchowej przez pedagogikę i nowe perspektywy edukacji jako edukacji międzykulturowej, jest już swego rodzaju wstępnym ćwiczeniem duchowym, gdyż wymaga ćwiczenia wyobraźni, przekraczania skamieniałych stereotypów i schematycznych podziałów.

Może powstać domniemanie, z którym trzeba się rozliczyć, że przytoczone idee Kotarbińskiego są tylko okazjonalnie podniesionym przez niego wątkiem, który został tu nadmiernie wyeksponowany. Otóż ta problematyka ma swe głębsze źródła: konsekwentnie prowadzoną refleksję nad rozumieniem kultury duchowej i jej doskonaleniem przez pedagogikę. Jednym z punktów odniesienia jest napisane w naznaczonym dramaturgią i tragicznością czasie II wojny światowej, opublikowane w 1947 roku, Życie duchowe. Zarys filozofii kultury autorstwa Bogdana Nawroczyńskiego (1882-1974) ${ }^{27}$. O tym

26 Dodaje: „I oby ci doszli do wyrównania antytez dzięki zrozumieniu tej [...] prawdy: ludzie godzą na ludzi głównie dlatego, że jedni boją się drugich, gdyż na mocy doświadczenia wiedzą, iż tamci dotąd grozili ciosami, sami bojąc się doznania ciosów, jeśli ich sami wymierzyć nie zechcą dość wcześnie" (Kotarbiński, 1970, s. 5).

27 „Zachęcam do lektury wyjątkowych rozpraw [...] Nawroczyńskiego, by z jednej strony nasza indywidualność odnalazła w nich bogate zaplecze duchowe, z drugiej zaś 
dziele - jak ujął to Kotarbiński w jubileuszowym wystąpieniu w 1962 roku - „nie mogę mówić bez wzruszenia. Życie duchowe [...] to dowód mocy wewnętrznej człowieka, który zdobył się na systematyczny wysiłek myślicielski, [...] zmuszając się do trwania w postawie dzielnej aktywności, gdy wszystko waliło się [...], gdy triumfował najeźdźca głoszący [...] hasła zagłady, a w tym zagłady polskiego życia duchowego [...]. Ludzie uparci [...] podtrzymywali [...] pasję i praktykę oporu... Wróg zdruzgotał narzędzia materialne naszej walki, ale życie duchowe jest w naszej mocy. Umocnijmy je więc uświadomieniem sobie jego istoty. Taki zamiar wciągnął [...] Profesora w sferę [...] filozofii kultury, dyscypliny uprawianej za czasów okupacji z wyróżniającym zainteresowaniem w polskim podziemiu intelektualnym. I oto powstała książka jedyna w swoim rodzaju. Jak mało o niej słychać i jak bardzo to jest niesprawiedliwe. [...] [Życie duchowe] winno być czytane i analizowane na seminariach socjologicznych i pedagogicznych ze względu na [...] aparaturę pojęciową i problematykę swoistą dyscypliny, której jest poświęcone i [...] jakość wyłożenia treści" (Kotarbiński, 1986, ss. 249-250).

Przytoczony fragment ukazuje „wysoką temperaturę”, z jaką Kotarbiński prezentuje walory Życia duchowego i postuluje obecność analiz Nawroczyńskiego w pedagogicznym namyśle. Zawarta została tu teza antropologiczna, że choć zniszczono narzędzia materialne, to „życie duchowe jest w naszej mocy"; ta teza jest jakby polemiczna wobec redukcjonistycznej tezy, wedle której „byt materialny całkowicie determinuje sferę świadomości i ducha”.

\section{Kształtowanie „samodzielności osobistej w środowisku ludzi samodzielnych” - perspektywy edukacji międzykulturowej}

Na aksjologiczne i formacyjne wymiary kontaktów z innością jako formą ćwiczenia duchowego uwagę zwraca Nikitorowicz:

„Społeczeństwo, które nie stwarza sytuacji do kontaktów z innością i [...] nie zawiera różnorodności [...] kulturowej, etnicznej, wyznaniowej, [...] [sprzyja] kształtowaniu postaw zamkniętych. [...] społeczeństwo, które dostarcza takich kontaktów, pielęgnuje i ceni inność, pozwala na

strony byśmy mogli stwarzać naszym wychowankom [...] jak najlepsze warunki dla ich rozwoju kulturowego" (Śliwerski, 2017, s. 14). Zob. Poglady pedagogiczne Bogdana Nawroczyńskiego i ich wspótczesne implikacje (2016); (Palka, 2010, ss. 17-20); (Kojs, 2010, ss. 56-74). 
trening obcości, stwarza warunki do spostrzegania rzeczywistości społecznej jako urozmaiconej. [...] jak twierdził Florian Znaniecki, twórczy rozwój [...] wymaga, aby człowiek uczestniczył [...] co najmniej w dwu kulturach, doceniając obie" (Nikitorowicz, 2001, s. 18) ${ }^{28}$.

Wyraźne jest tu nawiązanie do myśli Znanieckiego (1882-1958). Jest to trop poszukiwań pedagogicznych wart podjęcia. Do uprawiania edukacji międzykulturowej, także jako ćwiczenia duchowego, inspiruje bowiem Znaniecki w istotnym dla kształtowania relacji międzykulturowych i niejako współfundującym polską edukację międzykulturową dziele Ludzie teraźniejsi a cywilizacja przyszłości (Lwów - Warszawa 1934):

„Człowiek mądry to ten, który ceniąc różnorodne systemy kulturalne, umiejąc stosować różnorodne sprawdziany ważności, ceni kulturę w ogóle w całym jej bogactwie i różnorodności oraz pozytywnie interesuje się jej trwaniem i rozwojem. Systemy, w których [...] brał czynny udział [...] mogą być w jego oczach najcenniejszym fragmentem świata kultury, ale tylko fragmentem, czerpiącym swą cenność ze stosunku do całego świata. [...] Człowiek dobry traktuje każdą jednostkę i zbiorowość ludzką jako zasadniczo pozytywną wartość społeczną. [...] czyniąc więcej dla grupy, do której należy, niż dla [innych] grup, [...], uważa własne środowisko społeczne jako najcenniejszą dla niego [...] cząstkę ludzkości - ale tylko cząstkę, istniejącą w całości i dla całości. Porozumienie, sympatię, współdziałanie, zastępowanie altruistyczne, które uznaje za obowiązkowe wobec ludzi, mających względem niego podobne obowiązki, rozciąga [...] na wszystkich, na których życie [...] wpłynąć

28 O uczestnictwie w różnych kulturach i kształtowaniu się dzięki temu kompetencji do uczestnictwa w relacjach międzykulturowych zob. (Grabowska i Kania, 2017, ss. 35-48). „Udział w wymianie międzykulturowej dzięki doświadczeniu bezpośredniego kontaktu z inną rzeczywistością kulturową daje możliwość zwiększenia kompetencji kulturowych nie tylko u uczniów biorących udział w wymianie, ale także u członków społeczności lokalnych, w których przebywają. Uczestnicy wymian międzynarodowych po dogłębnym poznaniu kultury kraju goszczącego stają się osobami otwartymi na odkrywanie innych kultur, chętnymi do nabywania nowych kompetencji” (Grabowska i Kania, 2017, s. 46); Wiśniewski [Rafał] 2016. „[Żywe] dziedzictwo istnieje, jeśli trwa w [nim] wielogłosowość i wielopostaciowość pamięć. Homogenizacja świata [...] każdą tradycję zabija, [...] redukując [ją] do wykładni narzuconej instytucjonalnie” (Witkowski, 2007, s. 128). „W środowiskach etnicznie niejednolitych [...], [w których] zachodzą przenikania międzykulturowe, nikt nie jest monolitem kulturalnym. Byłoby tragedią, gdyby był. Oznaczałoby to [...] wyschnięcie tych różnorodnych źródeł, z których płynie nurt życia kulturalnego" (Hertz, 1988, s. 160). 
może, nie z obowiązku, lecz dlatego, że są to dlań normalne sposoby działania na ludzi. Jego funkcje [...] we właściwym środowisku nie tylko nie wyłączają w jego oczach, lecz implikują szerszą aktywność moralną, nabierają [...] [znaczenia jako wzór] postępowania względem ludzi w ogóle. [...] Moralność człowieka dobrego jest [...] otwartą moralnością - otwartą dla ekspansji wszechludzkiej. Mądrość i dobroć potrzebują [...] szerokiej wiedzy kulturowej, umysłowo pogłębionej i [...] wielu doświadczeń społecznych, etycznie zinterpretowanych [...]" (Znaniecki, 2001, ss. 304-306).

Osiągnięcie zarysowanego tu stanu wymaga działań edukacyjnych w sferze kultury duchowej i konsekwentnej pracy nad sobą: „musi zaistnieć nowy typ normalności życiowej, oparty nie na [...] gotowych system[ach] kulturalnych i przystosowywaniu się [...] [do] ludzi przystosowanych, lecz na tworzeniu nowych systemów kulturalnych i samodzielności osobistej w środowisku ludzi samodzielnych" (Znaniecki, 2001, s. 300). Efektywne kształtowanie takich przekonań i postaw, charakteryzujących się m.in. otwartą moralnością w relacjach międzykulturowych, zdolnością do tworzenia nowych systemów kulturalnych i wypracowywania samodzielności wymaga rozpoznań i ustaleń aksjologicznych.

Do rozumienia edukacji międzykulturowej także jako aktualnej dziś formy ćwiczenia duchowego odnieść można przenikliwe i prowokujące uwagi, które wobec kształtowania kultury duchowej w dociekaniach o indywidualności zawarł Jan Szczepański (1913-2004):

„Może jednak ludzkość zmęczona bankructwami tak wielu idei pedagogicznych i [...] nieudanymi próbami wychowania człowieka dobrego przez rozwijanie jego cech społecznych, wspólnych [...], [zechce] spróbować innej możliwości [...]: zwróceni[a] uwagi na cechy indywidualne właściwe [...] tylko jednemu człowiekowi, nie dzielone z innymi, [...] nie mogące być przedmiotem walki?” (Szczepański 1988, s. 265) ${ }^{29}$.

Jeśli w edukacji międzykulturowej zwraca się uwagę na Innego, który jest inny od innych, to - zgodnie z ideą wychowania ukierunkowanego „na rozwijanie cech właściwych tylko danej jednostce" (Szczepański, 1988, s. 260)

29 Przy czym trzeba uwzględniać współczesne pozory indywidualizacji: „Pogłębiająca się w wymiarach społecznych indywidualizacja stwarza nie tylko nowe możliwości kształtowania własnej osobowości [...] , ale i nowe uzależnienia i przymusy społeczne. Wyzwolenie się spod [...] nacisków społecznych w jednej dziedzinie może oznaczać podporządkowanie się innym uwarunkowaniom” (Mariański, 2011, s. 8). 
- zainteresowanie pedagogiki budzić powinno kształtowanie cech indywidualnych, nie dzielonych $\mathrm{z}$ innymi ${ }^{30}$. Może to okazać się pomocne w przezwyciężaniu w relacjach międzykulturowych destrukcyjnych antagonizmów.

\section{Wartości „ponadkulturowe” jako przedmiot ćwiczenia duchowego w edukacji międzykulturowej}

Jako kwestia będąca przedmiotem ćwiczenia duchowego, będącego formą uprawiania edukacji międzykulturowej, narzuca się sprawa wartości częstokroć określanych mianem "ponadkulturowych”. Chodzi tu zwłaszcza o prawdę, dobro i piękno, gdyż są to wartości ściśle zespolone z kształtowaniem (doskonaleniem) życia duchowego człowieka.

Podejmując kwestię wartości, należy uwzględnić, iż wysoce problematyczne jest samo pojęcie wartości, co zwięźle wyraził Władysław Tatarkiewicz (1886-1980): „Zdefiniowanie »wartości« jest trudne, jeśli w ogóle jest możliwe. Wyraz ten [...] zdaje się oznaczać swoiste, proste, nierozkładalne zjawisko [...]. Podobnie jak wyraz »byt« [...]. To, co wygląda na definicję »wartości« jest raczej zastąpieniem wyrazu przez inny wyraz mniej więcej to samo znaczący, na przykład »dobro«. Albo jest omówieniem” (Tatarkiewicz, 1978, s. 61). Rozprawiając o wartościach, trzeba być świadomym tych poważnych trudności.

Namysł nad sensem i rolą wartości edukacja międzykulturowa przesuwa w zajmujący ją kontekst wielokulturowości i pogranicza, pluralizmu religijnego i światopoglądowego, kształtowania kompetencji służących komunikacji międzykulturowej. Ten kontekst na swój sposób problematyzuje zwłaszcza „wartości ponadkulturowe” i w jakiejś mierze podaje w wątpliwość takie ich rozumienie, które zazwyczaj przyjmuje się poza tym kontekstem, gdy w środowiskach jednorodnych nie tylko aprobuje się te wartości, ale zarazem się je - jako coś oczywistego - wywyższa, absolutyzuje i uniwersalizuje, uznając je (jakby same przez się) za jakości transcendujące ograniczenia danej formacji kulturowej (za wartości transkulturowe).

W dyskursie współczesnej polskiej humanistyki i pedagogiki na kwestie wartości uznawanych za „ponadkulturowe” - a wśród nich na prawdę, dobro i piękno - szczególną uwagę zwracają m.in.: Władysław Stróżewski, Tischner,

30 Indywidualizm jako warunek uczestnictwa we wspólnocie rozpatruje: (Szczurek-Boruta, 2012, ss. 19-30). 
Mieczysław A. Krąpiec (1921-2008), Władysław Krajewski (1919-2006) ${ }^{31}$, Michał Heller, Anna Grzegorczyk ${ }^{32}$, Kazimierz Denek (1932-2016) ${ }^{33}$, Katarzyna Olbrycht ${ }^{34}$, Andrzej J. Sowiński ${ }^{35}$, Janina Kostkiewicz ${ }^{36}$ i Ewa Ogrodzka-Mazur ${ }^{37}$, wypracowując lub przyjmując różne ich rozumienie, także mocną (tzn. ugruntowaną ontologicznie) interpretację, natomiast nad pojęciem wartości absolutnej dociekania prowadzi Ryszard Wiśniewski ${ }^{38}$ i mogą być one bardzo przydatne w pedagogice.

Przed popełnieniem błędów jednostronności w zakresie kształtowania przekonań aksjologicznych i postaw moralnych, błędów, które mają destruk-

31 Zob. Krajewski, 1993, ss. 121-128.

32 Zob. Grzegorczyk, 2010.

33 O myśli pedagogicznej Denka i jej aksjologicznych wymiarach, zob.: (Rembierz, 2016, ss. 11-49).

34 Zob. (Olbrycht, 2000); (Olbrycht, 2012, ss. 89-104). „Wychowanie [...] zawsze jest wychowaniem do jakichś wartości. To wartości, rozumiane jako to, co cenne, wyznaczają z jednej strony cele wychowania (stanowiąc ich źródła i uzasadnienie), z drugiej - kryteria oceny działań wychowawczych. [...] zasadnicze problemy [...] związane z wychowaniem dotyczą [...] źródeł, wyboru, porządkowania i wewnętrznej spójności przyjmowanych wartości, wokół których buduje się formalne i nieformalne procesy wychowawcze" (Olbrycht, 2012, s. 91).

35 Zob. (Sowiński, 2013).

36 Zob. (Kostkiewicz, 2017, ss. 31-44). „[...] gdy w życiu człowieka pojawiają się [...] podstawowe wartości, takie jak prawda, dobro, piękno [...], [to] nadają mu etyczną orientację [...], wzmacniają uznanie tego życia za wartościowe. [...] naczelna triada w temporalnym wymiarze życia (przeszłość - teraźniejszość - przyszłość), pojawia się jednak aspektowo. W pewnym okresie mocniej angażuje nas dobro, w innym [...] dociekanie prawdy. Oznacza to nierówną obecność wartości w dziejach życia osoby: brak lub nadobfitość którejś ze względu na aktualne [...] uwarunkowania. [...] Przy założeniu, że cała triada wartości - prawda, dobro, piękno - wymaga ciągłej aktualizacji, nasuwa się dylemat: czy [...] nadobfitość którejś z wartości (i niedobór innej) [...] nie narusza ich uniwersalizmu" (Kostkiewicz, 2017, ss. 31-32). Zob. (Horowski, 2008, ss. 241-255).

37 Zob. (Ogrodzka-Mazur, 2007); m.in. o wartościach jako wyznacznikach rozwoju orientacji podmiotowej, o preferencjach aksjologicznych dzieci z klas I-III, ich rodziców i nauczycieli w środowiskach zróżnicowanych kulturowo, o językowym obrazie świata wartości i orientacjach wartościujących przejawianych przez dzieci, o kompetencji aksjologicznej dzieci, o strategiach kształtowania kompetencji aksjologicznej dzieci.

38 Zob. (Wiśniewski, 2005, ss. 169-178); (Wiśniewski, 2005a, ss. 29-42); (Wiśniewski, 2016, ss. 597-612). 
cyjne skutki zwłaszcza w edukacji i w relacjach międzykulturowych, słusznie przestrzega Tischner:

„Człowiek jednostronnie wyczulony na świat wartości, ale pozbawiony daru widzenia rzeczywistości, staje się [...] etycznym utopistą. Zapatrzony wprost w słońce, nie może widzieć świata. Chcąc zawsze zrobić to, co możliwie najlepsze, nie potrafi zrobić tego, co właściwe. Pozostaje mu [...] marzycielski rozhowor o wzniosłych ideach, [...], najwyższych wartościach ludzkich, dla których [...] brak czasu i brak miejsca" (Tischner, 1982, s. 56).

Aby nie popaść w iluzje utopii i pozory wartości, trzeba realistycznie spoglądać na złożoną i zróżnicowaną rzeczywistość, także w wymiarach relacji międzykulturowych.

Punkt wyjścia, który może przyczynić się do lepszego uzasadnienia doboru wartości uznawanych za ponadkulturowe, jako problematyki ćwiczeń duchowych w ramach edukacji międzykulturowej, stanowi refleksja Bertranda Russella (1872-1970), dotycząca kulturowego i egzystencjalnego znaczenia prawdy, dobra i piękna. Tym bardziej że ten myśliciel jest kojarzony nie tyle z respektem wobec - mających u źródeł konotacje religijno-metafizyczne ponadkulturowych wartości, co wiąże się go z poglądami wyzwolonymi od religijnych i metafizycznych przesłanek, a także od fundowanych na nich uniwersalizmów. Postrzega się go jako prominentnego przedstawiciela wolnej myśli w XX wieku. Przyjęcie takiego punktu wyjścia - podobnie jak przywołanie refleksji i tez Kotarbińskiego o wadze kultury duchowej w pedagogice - jest już co najmniej wstępem do ćwiczenia duchowego, które - choć nieco - zmienia schematyczne przyzwyczajenia i przełamuje utarte podziały.

„Przez cały wiek dziewiętnasty Prawda, Dobro i Piękno uchowały się jeszcze w umysłach prawdziwych ateistów” - z powagą stwierdza Russell (1997, s. 91), niejako lokując siebie wśród ateistów zachowujących respekt dla Prawdy, Dobra i Piękna. I wskazuje na nurty ideowe i procesy cywilizacyjne prowadzące do silnej destrukcji Prawdy, Dobra i Piękna: „Pragmatycy wyjaśnili, że Prawdą jest to, w co się opłaca wierzyć. Historycy obyczajów zredukowali Dobro do wymiaru obyczaju plemiennego. Artyści unicestwili piękno [...]" (Russell 1997, s. 89). Dokonało się radykalne odejście od dostrzegania „boskiej zasady" i jej obowiązywalności, uprzednio niejako wpisanej w strukturę świata i manifestującej się w tej strukturze, zarazem zaniknęło wewnętrzne poczucie, że powinno się jej przestrzegać: „Świat został oczyszczony nie tylko z Boga osobowego, ale i z boskiej zasady, stanowiącej pewien ideał, któremu 
człowiek powinien pozostać wierny”. Zaniku „boskiej zasady”, która wyrażała się przede wszystkim w postaci Prawdy, Dobra i Piękna, Russell nie uznaje za prometejski akt emancypacji, wskazuje negatywne skutki procesu zaniku dla właściwego kształtowania się człowieka i zabezpieczenia ludzkiej wolności: „W rezultacie prymitywnej i bezkrytycznej interpretacji rozsądnych skądinąd doktryn jednostka została pozbawiona wewnętrznej obrony przed presją społeczną". Występuje kryzys aksjosfery jako środowiska człowieka mającego dać punkty oparcia i orientacji aksjologicznej. Niepożądana sytuacja egzystencjalnych zagrożeń, wywołana przez promowanie „prymitywnych i bezkrytycznych” poglądów, staje się wyzwaniem dla pedagogiki w wymiarze dociekań teoretycznych i działań praktycznych. Stawia ona pedagogikę przed "palącą" kwestią, jak wspierać człowieka, którego pozbawia się „wewnętrznej obrony przed presją społeczną", obrony w dużej mierze zapewnianej przez Prawdę, Dobro i Piękno, które były niezależne od presji społecznej, a zostały unicestwione.

Wątek wyzwań pedagogicznych i „wewnętrznej obrony przed presją społeczną" wiąże się ze sprawą wychowawczych walorów ćwiczenia duchowego. Zarazem pilnym wyzwaniem pedagogicznym jest współczesny człowiek radykalnie zatracający kulturę duchową:

„Człowiek nowocześnie myślący, choć głęboko wierzy w mądrość swojej epoki, ma [...] skromne mniemanie o własnych zdolnościach. Chciałby pierwszy pomyśleć o tym, o czym myślą wszyscy, powiedzieć to, co [...] wypada, i odczuć to, co odczuwać należy. [...] tłumi swoją indywidualność, byle tylko zasłużyć na podziw stada" (Russell, 1997, s. 89).

Jeśli edukacja międzykulturowa ma funkcjonować w tym cywilizacyjnym kontekście, to rysuje się alternatywa: albo w edukacji respektuje i praktykuje się ćwiczenie duchowe, które kształtuje kulturę duchową i odmienne indywidualności, albo dokonuje się stłamszenia różnej od innych indywidualności, aby uzyskać „podziw stada”. Wówczas jednak nie ma owocnej komunikacji w relacjach międzykulturowych i twórczej wymiany wartości między odmiennymi indywidualnościami, gdyż jedynie można podporządkować się ujednolicającemu dyktatowi „stada”: myśleć i mówić tylko o tym, o czym mają myśleć i mówić wszyscy. Nie ma szans na spotkanie przedstawicieli istotnie odmiennych punktów widzenia i nie ma szans rozwoju jakiekolwiek zróżnicowanie w zakresie kultury duchowej i intelektualnej.

Z punktu widzenia zainteresowań edukacji międzykulturowej zaproponowane przez Russella podejście do problematyki prawdy, dobra i piękna 
wydaje się obiecujące. I zachęca do kontynuowania tak ukierunkowanych dociekań. A należy je prowadzić także ze względu na wymogi idące ze strony zasady pluralizmu ${ }^{39}$, gdyż trzeba uwzględniać i rozpatrywać - choćby „tylko” $\mathrm{w}$ formie ćwiczenia duchowego - pisane dużymi literami Prawdę, Dobro i Piękno, które częstokroć przedwcześnie posądza się o przeciwstawne pluralizmowi tendencje fundamentalistyczne i przemilcza się je, jako niewarte zainteresowania ${ }^{40}$.

O tym, jak prawda może być wartością istotną w edukacji międzykulturowej i jak bardzo prawda, aby nie stała się antywartością niszczącą relacje międzykulturowe, wymaga stosownego ćwiczenia duchowego od osób zaangażowanych w poznawanie i przekazywanie prawdy jako wartości w relacjach międzykulturowych, trzeba dyskutować na gruncie pedagogicznego i aksjologicznego namysłu nad edukacją międzykulturową. Należy dążyć do wypracowania stanowiska, które unika „zamknięcia prawdy” jako „naszej prawdy” („tylko naszej prawdy, a nie innych; my posiadamy prawdę, a inni jej nie mają i mieć nie mogą"), jak też unika „zamknięcia na prawdę”, uznaną wyłącznie za wartość pozorną i zwodniczą.

Można wskazać na wyraźne napięcie między dwoma biegunami, między klasyczną „myślą mocną”, której metafizyczny wyraz daje nurt platoński, a ponowoczesną „myślą słabą”, która jest dziś promowaną i dominującą w postaci przekonań relatywistycznych.

Klasyczną „myśl mocną” zwięźle wyraził Platon: „Prawda i u bogów nad wszystkimi góruje dobrami, i dla ludzi największym dobrem ze wszystkich" (Platon, Prawa, V, 730 c). We współczesnej myśli pedagogicznej do takiego stanowiska skłania się m.in. Denek, rozpatrując rolę wartości w edukacji: „Do [...] zadań edukacji należy kształtowanie wśród jej uczestników wartości uniwersalnych. Ogniskują się one wokół transcendentalnej triady: prawdy, dobra i piękna. Każda z tych wartości uszlachetnia poszczególne strony ludzkiej natury. Prawda doskonali intelekt, a dobro i piękno [...] wolę i uczucia" (Denek, 1996, s. 75). Za wartości uznaje się „to wszystko, co sprzyja człowieczeństwu":

39 O przemianach w rozumieniu i uczeniu się pluralizmu zob. (Rembierz, 2017, ss. 191-237); (Rembierz, 2017b, ss. 105-153); (Różańska, 2015).

40 „[Jeżeli w] społeczeństwach pluralistycznych nie brakuje wartości o charakterze partykularnym, często [...] ze sobą sprzecznych, co wywołuje niepewność i dezorientację, to [...] [odczuwa się] deficyt wartości ogólnie obowiązujących, o charakterze uniwersalnym, oraz brak kryteriów pozwalających odróżnić wartości trwałe od zmiennych opcji i przelotnych interesów, mylnie określanych jako wartości" (Mariański, 2011, s. 9). 
„Dobro formuje osobowość człowieka, wyzwala go od supremacji dóbr materialnych, chroni przed czynami niegodnymi, sprzyja rozwojowi jego duchowości, otwiera na potrzeby innych. [...] prawda chroni człowieka przed zakłamaniem. [...] pragnienie prawdy zawiera w sobie moc «podnoszenia duszy wzwyż ku światłu» (S. Weil). [...] [Piękno pozwala] znosić trudy życia" (Denek, 1994, ss. 19-20).

Tak artykułowane w pedagogice stanowisko w sprawie roli prawdy, dobra i piękna w edukacji poddaje się radykalnej krytyce w ujęciu myśli o wychowaniu jako „myśli słabej”:

„Obecność myśli silnej w pedagogice implikuje wizje wychowania ufundowane na wspornikach Prawdy, Dobra i Piękna, przyjmujących nienaruszalną, ostatecznie zastygłą postać metafizycznych archai. Ich obecności towarzyszy esencjalistyczna koncepcja podmiotu, zdolnego dosięgnąć istoty wolności równej Prawdzie na drodze wznoszącego moralnie wysiłku refleksji i pracy" (Męczkowska, 2003, s. 72).

W „myśli słabej” przyjmuje się więc inną antropologię niż w „myśli silnej”: człowiek najprawdopodobniej nie ma (nawet zarodkowo) zdolności poznawczych, które pozwalają mu na poznawanie prawdy, i nie ma wymogu, aby kształtować w nim te „esencjalne” zdolności.

Krytyka formułowana przez opcję „słabej myśli” o wychowaniu idzie śladem krytyki, którą wyrażał Richard Rorty (1931-2007): „Sprawy przybierają zły obrót [..], gdy filozofowie sztywno trzymają się takich pojęć, jak «prawda», «rozum», «uniwersalność» i próbują przekłuć je w racje na rzecz bycia otwartym na rozmowę i współpracę [...]" (Rorty, 2011, s. 39) ${ }^{41}$. Z punktu widzenia neopragmatyzmu Rorty'ego podejrzana i nieefektywna (wręcz przeciwskuteczna) staje się edukacja międzykulturowa, która z jednej strony działa na „rzecz bycia otwartym na rozmowę i współpracę” (w relacjach międzykulturowych), a z drugiej - postępuje jak „sztywno trzymający się pojęć: «prawda», «rozum», «uniwersalność»". Czy więc edukacja międzykulturowa powinna,

41 „[Społeczeństwo], którego członkowie nie będą pożądać absolutów ani też dbać o uniwersalną ważność, [...] [zbliży się do sprawiedliwości społecznej]. Porzucenie pojęcia [...] bezwarunkowych zobowiązań i zadowolenie z poszukiwania pragmatycznych kompromisów [...] [przybliżałoby] powstania społeczeństwa sprawiedliwego" (Rorty, 2011, s. 39). „[Powinniśmy przystać], że pojęcia prawdy i rozumu nie bazują na niczym poza konsensem wspólnoty idealnej [...], że nie sposób wykazać ludziom, którzy nie upatrują ideału we wspólnocie demokratycznej [...], że się mylą. Nie istnieje neutralny grunt, na którym moglibyśmy się oprzeć broniąc naszych ideałów moralnych" (Rorty, 2011, s. 40). Zob. (Szahaj, 1993, ss. 109-124); (Szubka, 2012). 
dzięki pragmatycznej dekonstrukcji, wyzbyć się aksjologicznego nasycenia, które postrzega się jako tylko zbyteczne i kłopotliwe obciążenie?

Aby przeciwstawić się zarysowanej radykalnie pragmatycznej dekonstrukcji edukacji międzykulturowej, która jest zespolona z napiętnowanymi kategoriami aksjologicznymi, takimi jak prawda, warto przywołać polemiczne argumenty, które wysunął Jacek Hołówka.

Po pierwsze: „Jeśli Rorty mówi, że prawda nie istnieje, tylko istnieją opinie, to jest to jego opinia i nic więcej. Jeśli [...] chciałby powiedzieć, że to szczera prawda i jednocześnie, że prawda nie istnieje, to wypowiada zdanie sprzeczne. Pragmatyzm zostaje sprowadzony do relatywizmu poznawczego i to jest [...] poważna rysa" (Hołówka, 2011, s. 152).

Po drugie: „Rorty nie odróżnia propagandy i ideologicznej indoktrynacji od rzetelnego badania i poszukiwania prawdy. [...] jakby nie wiedział, co to jest «pranie mózgu» i jak łatwo [...] wychować małe dzieci na [...] [obrońców] fanatycznej wiary" (Hołówka, 2011, s. 153).

Po trzecie: rezygnować z prawdy, bo „trudno ją zdefiniować, wiedząc, że tysiące ludzi poświęcało się dla niej [...], to niezrozumiałe żądanie. Rorty widzi niegodziwość [...] narzucania poglądów, nie widzi wzniosłości [...] dążenia do prawdy" (Hołówka, 2011, s. 154).

Te trzy argumenty w pewnej mierze odpierają napór pragmatycznej dekonstrukcji i osłabiają ostrze krytyki zwrócone też w stronę nasyconej aksjologicznie edukacji międzykulturowej.

Co do roli prawdy jako wartości w relacjach międzykulturowych, to trafne są uwagi Jacka Woźniakowskiego (1920-2012): „Prawdą trzeba się dzielić. [...] [Dzielenie się polega] na tym, żeby się z prawdą nie rozmijać [...], uznać jej nadrzędność wobec własnych i cudzych racji. [...] Mówiąc o prawdzie ciągle wypada się w paradoksy, jak ten, że [...] forma dzielenia się nią, to wspólnie, choćby z różnych stron, ku niej zmierzać" (Woźniakowski, 1988, s. 20-21). Jeśli uznaje się prawdę za istotną wartość w relacjach międzykulturowych, to trzeba podjąć się ćwiczenia duchowego, aby umieć uznawać jej nadrzędność, gdy wchodzi ona w spór z „naszymi prawdami”, które mogą utracić znamię prawdy.

W związku ze statusem prawdy w edukacji dotyczącej relacji międzykulturowych ważne jest spostrzeżenie Chantal Delsol, która rozpatrując relacje między prawdą i dobrem, zauważa, że w obecnej kulturze opartej na mitach występuje destrukcyjny „prymat dobra nad prawdą”. Ten prymat ma swe negatywne skutki: 
„prowadzi do kolonizacji poznania przez moralność. Prawdy historyczne i naukowe [...] [tłumiono w imię religii, bądź sławy księcia]. Dziś są one tłumione przez moralizującą wolę, tym potężniejszą, że jest ona przekonana, iż prowadzi walkę, w której stawką jest uświęcenie. Jako że wątpliwa prawdziwość mitów oparta jest tylko na powtarzaniu, jedynym sposobem, aby przekonać swoich rodaków jest nie tyle argumentacja (bo tu nie ma argumentów), ile propaganda w dziedzinie polityki i pamięci" (Delsol, 2011).

Jeśli w imię tak pojętego „prymatu dobra”, negującego sens niezależnego dociekania prawdy, pozostaje na podorędziu moralizująca propaganda, a wyklucza się nieskrępowane „prymatem dobra” przedstawianie i krytyczne rozpatrywanie argumentów z różnych źródeł, to także edukacja międzykulturowa poddana "prymatowi dobra” zostaje zredukowana do propagandy i indoktrynacji wyrażających czyjąś moralizującą wolę, autorytarnie określającą ideowo i politycznie pożądany kształt tożsamości i pamięci kulturowej.

Rozpatrując w trybie ćwiczenia duchowego istotną dla edukacji międzykulturowej problematykę ponadkulturowych wymiarów dobra, prawdy i piękna (ich statusu i funkcji), Stróżewski wskazuje na fundamentalność prawdy jako wartości, do której odniesione muszą zostać inne wartości: „nie ma wartości poza prawdą”, zarazem trzeba uznać, że do prawdy „dochodzi się najczęściej na drodze wątpienia" (Stróżewski, 2013, s. 382). Krytyczny dystans i wnikliwe rozeznanie wartości powinny towarzyszyć afirmacji ponadkulturowych wymiarów dobra, prawdy i piękna. Do tego dochodzi rozróżnienie wartości pełnych i niepełnych:

„Pełne [...] wystarczają do całkowitego i pozytywnego wypełnienia całej dziedziny ich realizacji, [...] niepełne, nie odznaczają się tą właściwością. Większość wartości należy do grupy drugiej. Ich niewystarczalność polega na tym, że im bardziej się [...] realizują, tym bardziej dopuszczają paralelną realizację wartości negatywnych [...]. Zapobiec temu można jedynie przez pozostawienie ich w stanie [...] niedopełnienia i otwarcia [...] [na] wartości pozytywne, które mogą [...] je uzupełniać. Takimi wartościami [...] niepełnymi są wolność, sprawiedliwość i wiele innych; [...] dopuszczają [one] jako dookreślenie ich charakterystyki przymiotnik «prawdziwe»: prawdziwa wolność, prawdziwa sprawiedliwość, [...]; możliwa jest nieprawdziwa wolność, nieprawdziwa sprawiedliwość [...]. W celu zapobiegania zwyrodnieniu wartości niepełnych należy w praktyce dążyć do realizacji odpowiednich wartości wobec nich komplementarnych" (Stróżewski, 2013, s. 380). 
Z rozróżnienia wartości pełnych i niepełnych wyprowadza się - mającą pedagogiczny wydźwięk - przestrogę, aby powściągliwie podchodzić do wartości niepełnych, takich jak wolność, zdających się przy braku wnikliwego rozeznania jawić jako wartości pełne i powstaje wówczas - również w niektórych koncepcjach pedagogicznych, pospiesznie absolutyzujących wolność lub sprawiedliwość - „pułapka aksjologiczna”, z której trudno się wydostać.

Respektowanie ponadkulturowego wymiaru dobra pozwala na krytyczne rozeznanie formacji kulturowych. „Każda wartość, [...] każda idea kierownicza formacji kulturowych, musi być odniesiona do dobra. Dobro samo w sobie przekracza wszelkie ograniczenia kulturowe, a z drugiej jednak strony wkracza w każdą z kulturowych formacji i uzasadnia ją jako dobro dla. Bez odniesienia do dobra żadna nie znajdowałaby swej dostatecznej racji. A [...] żadna nie jest w stanie dobra wyczerpać" (Stróżewski, 2013, s. 383). Zarysowana tu transcendencja dobra otwiera możliwość dyskusji o wartościach danej kultury, o możliwości i potrzebie wymiany wartości w relacjach międzykulturowych. „Transcendencja dobra wobec każdej idei kierowniczej umożliwia nam krytycyzm wobec [...] formacji kulturowych (także wobec tej, w której aktualnie żyjemy), [...] możliwość przejścia do innej, która się jawi jako lepsza, [...] ściślej związana z dobrem samym" (Stróżewski, 2013, ss. 383-384). Metafizyczna medytacja nad dobrem jako „dobrem samym” okazuje się ściśle związana z praktyką edukacji międzykulturowej ukierunkowanej na kształtowanie kultury relacji międzykulturowych.

Uznaniu ponadkulturowych wymiarów dobra towarzyszy zestaw niezbędnych pytań - niejako diagnostycznych pytań kontrolnych - wobec aksjologicznych podstaw i programów danej formacji kulturowej, pytań, które można uszczegółowić:

„Czy zdajemy sobie jednak do końca sprawę, na jakich ideach regulatywnych programy te są oparte? Czy prawdziwie odczytujemy leżące u ich podstaw wartości? Czy wiemy, jak dalece są one niepełne - bo niepełne być muszą? [...] czy przestrzegamy postulatu realizowania przez nie dobra dla i dobra samego w sobie?" (Stróżewski, 2013, s. 384).

W konkluzji Stróżewski przyjmuje za własną - wartą przytoczenia i poddania pod dalszą dyskusję - „mocną tezę”, że „tylko dzięki tym trzem: prawdzie, dobru i pięknu tworzyć możemy prawdziwą kulturę. I możemy żyć jako ludzie. [...] do natury człowieka jako człowieka należy postulat jej przekraczania przez kulturę, a do istoty kultury - wieczne przekraczanie siebie ku wartościom najwyższym” (Stróżewski, 2013, s. 388). Ta „mocna teza” jest 
wszakże osadzona w analizach i argumentacji, które zdają się przemawiać na jej rzecz, a co najmniej pozwalają ją przywołać jako heurystycznie płodną.

Co do sensu piękna jako istotnej acz spornej wartości w relacjach międzykulturowych można - przez analogię - przywołać rozeznanie roli piękna w miłości, gdy jawi się ono jako zespolone z kształtowaniem (trudnej do uformowania) postawy bezinteresowności:

„Kiedy doświadczamy piękna [...], chcemy być obok - bezinteresownie. [...] poprzez piękno człowiek uczy się bezinteresowności. W życiu codziennym gonimy za [...] interesem. Kiedy[...] pojawi się coś pięknego, ktoś piękny, [...] stajemy i podziwiamy bezinteresownie. Piękno jakby rozbija nasz świat codziennego interesu" (Tischner, 2011, ss. 328-329).

Piękno występuje, gdy dokonuje się przełamanie kalkulacji zysków i strat, co pozwala też bezinteresownie podejść do wartości ujawniających się w relacjach międzykulturowych.

Bezinteresowność w wielu sytuacjach napięć i antagonizmów okazuje się jedną z niezbędnych postaw w kształtowaniu relacji międzykulturowych. Sens tej postawy dookreśla Andrzej Grzegorczyk (1922-2014), rozpatrując psychiczną osobliwość człowieka:

„Wiele osób przeżywa w życiu moment, w którym myśl o interesach zostaje [...] zawieszona i człowiek pragnie tylko zrozumieć [...]. [Czasem na] chęć bezinteresownego zrozumienia rzeczywistości najbardziej uodpornieni są [...] pracownicy nauki, wciągnięci w [...] [system], który organizuje i [...] ogranicza całą ich intelektualną działalność. Związani zadaniami badawczymi, nie potrafią spojrzeć na całość problematyki, [...] zachwycić się [...] zjawiskiem lub prostą prawdą. Tkwią w dyskursie uwarunkowanym przyjętymi założeniami, a nie umieją zdobyć się na kontemplację przedmiotu [...], [a kontemplacja] stanowi często najważniejszą postać poznania, przynoszącą zrozumienie" (Grzegorczyk, 2003, s. 74).

Postulat, aby umieć „spojrzeć na całość”, przywołuje cele ćwiczenia duchowego, które są zbieżne z celami edukacji międzykulturowej. Do wymogu postawy bezinteresowności w relacjach międzykulturowych jako wzajemnej wymianie wartości da się odnieść myśl, że:

„Bezinteresowne spojrzenie na siebie umieszczonego w strukturze świata można traktować jako duchowo cenny stosunek do całości rzeczywistości. Spojrzenie bezinteresowne z punktu widzenia własnego trwania i [...] ekspansji, kontemplacja własnego umiejscowienia w całości bytu 
mogą być zaliczone do [cennych] postaw duchowych" (Grzegorczyk, 2003, s. 82).

Rozwijanie w teorii i praktyce edukacji międzykulturowej wymaga też tego rodzaju „bezinteresownego spojrzenia”, które zyskuje się i praktykuje dzięki ćwiczeniu duchowemu i pogłębionemu rozeznawaniu świata wartości.

\section{Uwagi końcowe}

Przedłożona propozycja rozpatrywania edukacji międzykulturowej w perspektywie klasycznie rozumianego ćwiczenia duchowego oraz refleksji nad statusem ponadkulturowych wymiarów dobra, prawdy i piękna, ma przede wszystkim służyć jako inspiracja dla dalszego rozwoju teorii i praktyki edukacji międzykulturowej. Jeśli w jakiejś mierze stanowić będzie zachętę do uprawiania edukacji międzykulturowej także jako ćwiczenia duchowego i odsłoni coś z ponadkulturowych wymiarów dobra, prawdy i piękna, to spełni swe zadanie. Jeśli skłoni do sformułowania argumentów przeciw obranej tu linii rozumowania i wysunięcia odmiennej propozycji rozumienia edukacji międzykulturowej, to pozwoli lepiej uchwycić słabość rozpatrywanych tu koncepcji, a tym samym wzmocni też rozwój edukacji międzykulturowej.

Przedstawione dociekania mogą być odczytane jako przykład współdziałania refleksji pedagogicznej i filozoficznej, jako ich wspólny wkład do edukacji międzykulturowej. Mogą też być zachętą do rozwijania refleksji filozoficznej i aksjologicznej nad problematyką podejmowaną przez pedagogikę i edukacją międzykulturową. Na potrzebę zintensyfikowania tak ukierunkowanej refleksji filozoficznej i aksjologicznej oraz potrzebę towarzyszącej jej metarefleksji (jako „nowego myślenia o filozofii”) uwagę zwraca Marek Szulakiewicz:

„[W] świecie otwartym interkulturowo, w rzeczywistości dyskursów interkulturowych, jest nie tylko miejsce dla interkulturowej filozofii, ale też musi się wymagać nowego myślenia o filozofii i metafizyce. Myślenie filozoficzne staje tu przed zadaniem ustanowienia pola interkulturowego, którego ukonstytuowanie musi wyprzedzać dialog interkulturowy. Jest to nowa postać filozofii, w której droga prowadzi od monokulturowości ku interkulturowości” (Szulakiewicz, 2012, s. 177).

Rozwijanie pogłębionego namysłu w zakresie - mierzącej się na wiele sposobów z otwartym interkulturowo światem - pedagogiki międzykulturowej (wraz z towarzyszącą jej refleksją metapedagogiczną) może przyczyniać się 
do przechodzenia „od monokulturowości ku interkulturowości” w innych - współdziałających i współgrających z nią - obszarach i formach refleksji humanistycznej. Inspiracje do dalszego rozwijania pedagogiki (edukacji) międzykulturowej i do nowych postaci filozofii międzykulturowej można czerpać m.in. - jak to czyniono w prowadzonych powyżej analizach - z klasycznych koncepcji ćwiczeń duchowych i z poszukiwań (intuicji, dyskusji) współczesnej myśli filozoficznej.

Na zakończenie, nawiązując do podnoszonego już postulatu słownika (leksykonu) edukacji międzykulturowej (Rembierz, 2017a, ss. 61-62), można stwierdzić, że w takim opracowaniu uwzględnienia wymagają sposoby rozumienia pojęć z zakresu aksjologii (m.in. „wartości ponadkulturowe”, „wartości uniwersalne"), jak też inspiracje i przesłanki dla edukacji międzykulturowej (niejako „zarodki” jej wiodących pojęć i kategorii) w koncepcjach ćwiczenia duchowego, które rozwijały różne starożytne szkoły. Tak oto przecina się z sobą i dopełnia prospektywne i retrospektywne spojrzenie na koncepcje i zadania edukacji międzykulturowej.

\section{Bibliografia}

Baniak, J. 2013. Wielowymiarowość i konteksty kulturowe duchowości religijnej a inne formy duchowości. Humaniora. Czasopismo Internetowe. 2 (2), ss. 13-37.

Chmielewski, M. 2017. Duchowość chrześcijańska na tle współczesnych koncepcji duchowości. Zarys problematyki. Roczniki Teologiczne. 5, (64), ss. $159-179$.

Cudowska, A. 2003. Postawa „niewspółobecności” antropologii filozoficznej M. Bachtina w dialogu międzykulturowym. W: Nikitorowicz, J., Halicki, J. i Muszyńska, J., red. Międzygeneracyjna transmisja dziedzictwa kulturowego. Globalizm versus regionalizm. Białystok: Wydawnictwo Uniwersyteckie „Trans Humana”, ss. 127-135.

Cudowska, A. 2011. Dialog w edukacji międzykulturowej - kształtowanie przestrzeni spotkania z Innym. Pogranicze. Studia Społeczne. XVII, ss. 69$-83$.

Dancák, P. 2011, Filozofická reflexia starostlivosti o dušu v čase krízy. W: Šoltés, R., Hruška, D. i Dancák, P. red. Disputationes quodlibetales. Duša $\mathcal{E}$ Európa. Prešov: Prešovská univerzita v Prešove, ss. 211-220. 
Delsol, Ch. 2011. Prawda i dobro dzisiaj (referat 25.10.2011: L'effacement de la vérité par le bien. Wymazywanie prawdy przez dobro. Międzynarodowy Kongres Tischnerowski. Prawda i Dobro), http://tischner.pl/aktualnosc/484/1/kongres-tischnerowski-relacja-z-pierwszego-dnia (zob. Delsol, Ch. 2013. W: Bobko, A. i Karolczak, M. red. Wobec Dobra i Prawdy w dialogu z Tischnerem. Kraków: Wydawnictwo Instytut Myśli Józefa Tischnera, Europejska Sieć Pamięć i Solidarność).

Denek, K. 1994. Wartości i cele edukacji szkolnej. Poznań - Toruń: „Edytor”.

Denek, K. 1996. Uniwersalne wartości edukacji szkolnej. Dydaktyka Literatury. XVI, ss. 69-90.

Gara, J. 2008. Pedagogiczne implikacje filozofii dialogu. Kraków: WAM.

Gara, J. 2010. Filozofia dialogu i jej implikacje pedagogiczne. Paedagogia Christiana. 25 (1), ss. 137-148.

Grabowska, B. i Kania, K. 2017. Codzienne zdziwienie? Uczestnicy wymian międzynarodowych wobec szoku kulturowego. Lubelski Rocznik Pedagogiczny. 3, (XXXVI), ss. 35-48.

Grzegorczyk, A. [Andrzej] 2003. Psychiczna osobliwość człowieka. Warszawa: „Scholar".

Grzegorczyk, A. [Anna] 2010. Ponad kulturami. Uniwersalizm Edyty Stein. Poznań: Wydawnictwo Poznańskie.

Hadot, P. 1992. Filozofia jako ćwiczenie duchowe. Warszawa: IFiS PAN (Hadot, P. 1981. Exercices spirituels et philosophie antique. Paris: Études Augustiniennes).

Heller, M. 2006. Czy filozofia może być „sposobem na życie”? Zagadnienia Filozoficzne w Nauce. XXXIX, ss. 132-140.

Hertz, A. 1988. Żydzi w kulturze polskiej. Warszawa: Biblioteka „Więzi”.

Hołówka, J. 2011. Pragmatyczna dekonstrukcja filozofii. Przeglad Filozoficzny - Nowa Seria. 3 (79), ss. 137-162.

Horowski, 2008. Pedagogika tomistyczna a pedagogika wartości. Paedagogia Christiana. 21 (1), ss. 241-255.

Jaskóła, S. i Korporowicz, L. 2013. Międzykulturowa kompetencja komunikacyjna jako transgresja. Pogranicze. Studia Społeczne. XXI, ss. 121-138.

Kabzińska, I. 2008. Spotkanie z innym w dialogu międzykulturowym. Etnografia Polska. 1-2, (L II), ss. 21-41.

Kasperek, A. 2012. Wolność spod znaku undergroundu. Duchowość (po)nowoczesna $w$ perspektywie hermeneutyki kultury i socjologii religii. Kraków: Zakład Wydawniczy „Nomos”.

Kojs, W. 2010. Edukacyjne i pedagogiczne aspekty koncepcji życia ducho- 
wego Bogdana Nawroczyńskiego. W: Życie i dzieto profesora Bogdana Nawroczyńskiego, wybitnego Zagłębianina: w osiemdziesiąta rocznice publikacji „Zasad nauczania”. Sosnowiec: Wyższa Szkoła Humanitas, ss. $56-74$.

Korporowicz, L. 1997. Wielokulturowość a międzykulturowość: od reakcji do interakcji. W: Kempny, M., Kapciak, A. i Łodziński, S. red. U progu wielokulturowości. Nowe oblicza społeczeństwa polskiego. Warszawa: Oficyna Naukowa, ss. 64-72.

Kostkiewicz, J. 2004. Duchowość jako wartość i obszar wspierania rozwoju człowieka dorosłego. W: Kostkiewicz, J. red. Aksjologia edukacji dorostych. Lublin: KUL, ss. 141-152.

Kostkiewicz, J. 2017. Temporalna zmienność życia wartościowego a uniwersalizm wartości w świetle filozofii i pedagogiki realistycznej. Polska Myśl Pedagogiczna. 3, ss. 31-44.

Kotarbiński, T. 1970. Perspektywy myśli pedagogicznej. Studia Filozoficzne. 1 (62), ss. 3-10.

Kotarbiński, T. 1986. Przemówienie na uroczystym posiedzeniu Rady Wydziału Pedagogicznego UW, zwołanym na dzień 10 IV 1962 r. dla uczczenia 80-lecia profesora dra Romana Bogdana Nawroczyńskiego. W: Kotarbiński, T. i Kotarbińska, J. red. Myśli o ludziach i ludzkich sprawach. Wrocław: Zakład Narodowy im. Ossolińskich, ss. 248-250.

Kraczoń, K. 2014. Rola współczesnych jarmarków miejskich w upowszechnianiu niematerialnego dziedzictwa kulturowego (na przykładzie Jarmarku Jagiellońskiego w Lublinie). Studia Etnologiczne i Antropologiczne. 14 (Globalizacja jako wyzwanie dla zachowania i upowszechniania dziedzictwa kulturowego w Europie Środkowo-Wschodniej), ss. 143-153.

Krajewski, W. 1993. Wartości w nauce. W: Karłowicz, D., Lipiec, J., Markiewicz, B. i Szymańska, B. red. Wartość bycia. Kraków - Warszawa: PTF, Ss. $121-128$.

Lewowicki, T. 2000. W poszukiwaniu modelu edukacji międzykulturowej. W: Lewowicki, T., Ogrodzka-Mazur, E. i Szczurek-Boruta, A. red. Edukacja międzykulturowa $w$ Polsce $i$ na świecie. Katowice: UŚ, ss. 21-35.

Lewowicki, T. 2001. Szkic do teorii zachowań tożsamościowych. W: Lewowicki, T. i Ogrodzka-Mazur, E. red. W poszukiwaniu teorii przydat$n y c h w$ badaniach międzykulturowych. Cieszyn: UŚ - Filia w Cieszynie, Ss. $159-165$.

Lewowicki, T. 2011. Wprowadzenie. W: Lewowicki, T., Szczurek-Boruta, A. i Suchodolska, J. red. Pedagogika międzykulturowa wobec wykluczenia 
spotecznego i edukacyjnego. Cieszyn - Warszawa - Toruń: Wydział Etnologii i Nauk o Edukacji Uniwersytetu Śląskiego, Wyższa Szkoła Pedagogiczna ZNP w Warszawie, Wydawnictwo Adam Marszałek, ss. 9-13.

Lewowicki, T. 2013. Edukacja wobec odwiecznych i współczesnych problemów świata - konteksty i wyzwania edukacji międzykulturowej. Edukacja Międzykulturowa. 2, ss.19-37.

Mariański, J. 2011. Wartości moralne w zmieniającym się społeczeństwie polskim. Edukacja Humanistyczna. 1 (24), ss. 7-24.

Mariański, J. 2013. Sekularyzacja. Desekularyzacja. Nowa duchowość. Studium socjologiczne. Kraków: Zakład Wydawniczy „Nomos”.

Mariański, J. 2015. Nowa duchowość jako megatrend społeczno-kulturowy - mit czy rzeczywistość? Uniwersyteckie Czasopismo Socjologiczne. 13, Ss. $22-45$.

Mariański, J. 2016. Godność ludzka jako wartość społeczno-moralna: mit czy rzeczywistość? Studium interdyscyplinarne. Toruń: Wydawnictwo Adam Marszałek.

Milerski, B. 2008. Pedagogika dialogu: filozoficzne inspiracje i perspektywy. Paedagogia Christiana. 21 (1), ss. 29-42.

Męczkowska, A. 2003. Myśl o wychowaniu jako myśl słaba - pomiędzy fundamentalizmem a relatywizmem pedagogicznej refleksji. W: Sztobryn S. i Śliwerski, B. red. Idee pedagogiki filozoficznej. Łódź: UŁ, ss. 70-81.

Nikitorowicz, J. 2001. Pogranicze - tożsamość - edukacja międzykulturowa. Białystok: Wydawnictwo Uniwersyteckie „Trans Humana”.

Nikitorowicz, J. 2001a. Od podmiotowości do międzykulturowości i z powrotem. Próba interpretacji niektórych perspektyw teoretycznych. W: Lewowicki, T. i Ogrodzka-Mazur, E. red. W poszukiwaniu teorii przydatnych $w$ badaniach międzykulturowych. Cieszyn: UŚ - Filia w Cieszynie, ss. 15-27.

Nikitorowicz, J. 2011. Edukacja międzykulturowa w kontekście dylematów integracji imigrantów w warunkach wielokulturowości. W: Paszko, A. red. Edukacja międzykulturowa w Polsce wobec nowych wyzwań. Kraków: Stowarzyszenie Willa Decjusza, ss. 11-29.

Nikitorowicz, J. 2011a. Od Federacji Zespołów Badań Pogranicza do Stowarzyszenia Wspierania Edukacji Międzykulturowej. Pogranicze. Studia Społeczne. XVII, ss. 7-18.

Nikitorowicz, J. 2014. Wielokulturowość - Pogranicze - Człowiek pogranicza. Ku paradygmatowi współistnienia, zachowania i kreowania pokoju. Drohiczyński Przeglad Naukowy. Wielokulturowe Studia Drohiczyńskiego Towarzystwa Naukowego. 6, ss. 171-189. 
Nowak, M. 2012. Pedagogiczny profil nauk o wychowaniu. Studium zodniesieniami do pedagogiki pielegniarstwa. Lublin: KUL.

Ogrodzka-Mazur, E. 2007. Kompetencja aksjologiczna dzieci w młodszym wieku szkolnym. Studium porównawcze środowisk zróżnicowanych kulturowo. Katowice: UŚ.

Ogrodzka-Mazur, E. 2010. Przyjaźń. W: Pilch, T. red. Encyklopedia pedagogiczna XXI wieku. Suplement A-Ż. Warszawa: Wydawnictwo Akademickie „Żak”, ss. 427-430.

Ogrodzka-Mazur, E. i Szczurek-Boruta, A. 2012. Działalność naukowo-badawcza, dydaktyczna i organizacyjna Zakładu i Katedry Pedagogiki Ogólnej Uniwersytetu Śląskiego na Wydziale Etnologii i Nauk o Edukacji w latach 1989-2012. Wokół cieszyńskiej szkoły badań pogranicza Profesora Tadeusza Lewowickiego. W: Szczurek-Boruta, A. i Ogrodzka-Mazur, E. red. Poza paradygmaty. Pedagogika międzykulturowa. T. 2. Księga pamiatkowa dedykowana Profesorowi Tadeuszowi Lewowickiemu. Cieszyn - Toruń: Wydział Etnologii i Nauk o Edukacji Uniwersytetu Śląskiego, Wydawnictwo Adam Marszałek, ss. 19-40.

Ogrodzka-Mazur, E. 2014. Cieszyńska szkoła badań pogranicza Profesora Tadeusza Lewowickiego. Pedagogika Przedszkolna $i$ Wczesnoszkolna. 22 (4), ss. 25-39.

Olbrycht, K. 2000. Prawda, dobro i piękno w wychowaniu człowieka jako osoby. Katowice: UŚ.

Olbrycht, K. 2012. Wychowanie do wartości - w centrum aksjologicznych dylematów współczesnej edukacji. Paedagogia Christiana. 1 (29), ss. 89-104 .

Palka, S. 2010. Aktualność sposobu ujmowania „nauczania kształcącego” przez Bogdana Nawroczyńskiego. W: Życie i dzieło profesora Bogdana Nawroczyńskiego wybitnego Zagłębianina: $w$ osiemdziesiąta rocznicę publikacji „Zasad nauczania”. Sosnowiec: Wyższa Szkoła Humanitas, ss. 17-20.

Pasek, Z. 2010. O przydatności pojęcia duchowość do badań nad współczesną kulturą. W: Libiszowska-Żółtkowska, M. i Grotowska, S. red. Religijność i duchowość - dawne i nowe formy. Kraków: Zakład Wydawniczy „Nomos”, ss. 56-65.

Pasek, Z. 2013. Nowa duchowość. Konteksty kulturowe. Kraków: Wydawnictwo Aureus.

Rarot, H. 2015. Od filozoficznej nieakceptacji do dialogu z obcością. Związki filozofii z podróżą i turystyką. Turystyka Kulturowa. 3 (marzec), ss. 68-78. Rembierz, M. 2007. Ethos edukacji i jej filozoficzny logos. Elementy filozofii 
edukacji w dociekaniach Tadeusza Kotarbińskiego. Studia z Filozofii Polskiej. 2, ss. 341-354.

Rembierz, M. 2014. Tropy transcendencji... Współczesne myślenie religijne wobec pluralizmu światopoglądowego i relacji międzykulturowych. Świat i Stowo. 2 (23), ss.17-50.

Rembierz, M. 2016. Pedagogiczna pasja jako filozofia życia. Pamięci Profesora Kazimierza Denka. Studia z Teorii Wychowania. 1 (14), ss. 11-49.

Rembierz, M. 2016a. Realizm metafizyczny jako inspiracja myśli pedagogicznej. O antropologiczno-pedagogicznej refleksji Stefana Swieżawskiego i jej znaczeniu dla teorii wychowania oraz analiz metapedagogicznych. Polska Myśl Pedagogiczna. 2, ss. 135-174.

Rembierz, M. 2017. Uczenie się pluralizmu i kształtowanie tożsamości religijnej w kontekście kulturowych i światopoglądowych odmienności - między tradycyjnym zróżnicowaniem a współczesnym pluralizmem. Politeja. Pismo Wydziału Studiów Międzynarodowych i Politycznych Uniwersytetu Jagiellońskiego. 46, ss. 191-237.

Rembierz, M. 2017a. Kultura intelektualna, wątpliwości metodologiczne i refleksja metapedagogiczna w rozwijaniu teorii i praktyki edukacji międzykulturowej. Edukacja Międzykulturowa. 2 (7), ss. 37-67.

Rembierz, M. 2017b. O uczeniu się pluralizmu w/dzięki pedagogice. Pluralistyczne perspektywy pedagogiki i różnorodne oblicza pluralizmów w krytycznym rozpoznaniu refleksji metapedagogicznej. Studia Pedagogiczne. LXX, ss. 105-153.

Rembierz, M. 2018. Spór o koncepcję społeczeństwa i wartość jednostki jako kontekst i wyzwanie dla polskiej myśli pedagogicznej. Polska Myśl Pedagogiczna. 2, ss. 59-90.

Rorty, R. 2011. Autobiografia intelektualna. Przeglad Filozoficzny - Nowa Seria. 3 (79), ss. 9-41.

Różańska, A. 2015. Edukacja religijna młodzieży w warunkach pluralizmu religijnego w wybranych krajach Europy Srodkowo-Wschodniej: Polska, Czechy, Stowacja, Węry) - studium porównawcze. Cieszyn - Toruń: Wydział Etnologii i Nauk o Edukacji Uniwersytetu Śląskiego, Wydawnictwo Adam Marszałek.

Russell, B. 1997. Szkice niepopularne. Warszawa: Książka i Wiedza.

Skarga, B. 1999. W Collège de France. W: Skarga, B. O filozofię bać się nie musimy. Szkice z różnych lat. Warszawa: PWN, ss. 325-327.

Skowronek, K. i Pasek, Z. 2013. Wstęp. Czy istnieje duchowość bez sacrum? Kilka słów o duchowości niereligijnej. W: Pasek, Z., Skowronek, K., Skow- 
ronek, K. i Tyrała, R. red. Pozareligijne wymiary duchowości. Kraków: Wydawnictwo LIBRON - Filip Lohner, ss. 7-16.

Sobecki, M. 2014. Komunikacja międzykulturowa w wymiarze religijnym jako wyzwanie edukacyjne. W: Nikitorowicz, J., Muszyńska, J. i Boćwińska-Kiluk, B. red. Od wielokulturowości miejsca do międzykulturowości relacji społecznych. Wspótczesne strategie kreowania przestrzeni życia jednostki. Warszawa: Wydawnictwo Akademickie „Żak”, ss. 107-118.

Socha, P. 2014. Przemiana duchowa jako kluczowe pojęcie psychologii rozwoju człowieka. Psychologia Rozwojowa. 3 (19), ss. 9-22.

Sowiński, A. J. 2013. Szkice do teorii wychowania kreatywnego. Kraków: Oficyna Wydawnicza „Impuls”.

Stachewicz, K. 2013. O filozofii chrześcijańskiej. Kilka uwag z perspektywy historycznej i futurologicznej. Logos $i$ Ethos. 2 (35), ss. 219-234.

Stróżewski, W. 2013. Ponadkulturowe wymiary dobra, prawdy i piękna. W: Stróżewski, W. Logos, wartość, mitość. Kraków: Znak, ss. 361-388.

[Swieżawski, S. 1992] Odrodzenie religijne - między teokracją a new age. Z profesorem Stefanem Swieżawskim rozmawiają Karol Tarnowski i Stefan Wilkanowicz. Znak. 10 (449), ss. 63-72.

Szahaj, A. 1993. Richarda Rorty'ego humanizm bez metafizyki i jego etyczno-polityczne implikacje. Etyka. 26, ss. 109-124.

Szczepański, J. 1988. O indywidualności. Warszawa: Instytut Wydawniczy Związków Zawodowych.

Szczurek-Boruta, A. 2007. Edukacja i odkrywanie tożsamości w warunkach wielokulturowości. Szkice pedagogiczne. Katowice - Cieszyn - Kraków: Wydział Etnologii i Nauk o Edukacji Uniwersytetu Śląskiego, Oficyna Wydawnicza „Impuls”.

Szczurek-Boruta, A. 2012, Indywidualizm warunkiem uczestnictwa we wspólnocie - perspektywa edukacji międzykulturowej. Studia z Teorii Wychowania. 2-3 (5), ss. 19-30.

Szubka, T. 2012. Neopragmatyzm. Toruń: UMK.

Szulakiewicz, M. 2012. O człowieku w czasach trudnych. Toruń: UMK.

Szutta, N. 2010. Normatywność pojęcia przyjaźni i jego miejsce we współczesnych teoriach etycznych. Roczniki Filozoficzne. 2 (LVIII), ss. 125-151. Śliwerski, B. 2017. Wprowadzenie. W: Śliwerski, B. i Walancik, M. red. Wybór tekstów Profesora Bogdana Nawroczyńskiego. Kraków: Oficyna Wydawnicza „Impuls”, ss. 7-15.

Śliwerski, B. 2010. Myśleć jako pedagog. Sopot: GWP.

Śliz, A. i Szczepański, M. S. 2015. Wielokulturowość współczesna: terminy, 
idee, teorie i aktorzy. Górnoślaskie Studia Socjologiczne. Seria Nowa. 6, ss. 13-27.

Śliz, A., 2017. Wielokulturowość: stygmat wspótczesnego świata? Próba analizy socjologicznej. Opole: UO.

Tatarkiewicz, W. 1978. Pojęcie wartości, czyli co historyk filozofii ma do zakomunikowania historykowi sztuki. W: Tatarkiewicz, W. Paraerga. Warszawa: PWN, ss. 60-73.

Tischner, J. 1981. Etyka solidarności. Kraków: Znak.

Tischner, J. 1982. Etyka wartości i nadziei. W: Hildebrand, D., Kłoczowski, J. A. i Tischner, J. Wobec wartości. Poznań: W Drodze, ss. 51-148.

Tischner, J. 2011. Nadzieja czeka na słowo. Rekolekcje 1966-1996. Kraków: Znak.

Trzcińska, I. 2013. O duchowości inaczej. Coaching w perspektywie przemian kultury współczesnej. Kraków: UJ.

Walczak, A., Wróbel, A. i Wasilewski, M. red. 2016. Poglady pedagogiczne Bogdana Nawroczyńskiego i ich wspótczesne implikacje. Łódź: UŁ.

Wielecki, K. 2014. Między różnorodnością kulturową i rozpadem tożsamości. Uniwersyteckie Czasopismo Socjologiczne. 9, ss. 41-52.

Wielecki, K. 2016. Kryzys cywilizacyjny i sztuka serfowania. W: Zagórski, Z. i Kamykowski, S. red. (Nie)tad a (od)budowa cywilizacji. Wrocław: UW, ss. $45-58$.

Wierzbicki, A. M. 2018. Jarmark Jagielloński. W: Wierzbicki, A. M. Ulica Bernardyńska. Lublin: Fundacja Chrońmy Dziedzictwo, s. 12.

Wiśniewski, R. [Rafał] 2016. Transgresja kompetencji międzykulturowych. Studium młodzieży akademickiej. Warszawa: UKSW.

Wiśniewski, R. [Ryszard] 2005. W stronę pojęcia wartości absolutnej. W: Tyburski, W. i Wiśniewski, R. red. Rozprawy filozoficzne. Księga pamiatkowa $w$ darze Profesorowi Józefowi Pawlakowi. Toruń: UMK, ss. 169-178.

Wiśniewski, R. 2005a. O trudnościach wpływania etyki na moralność, czyli o różnych wymiarach i granicach absolutyzacji i deabsolutyzacji etyki. W: Zamiara, K. red. Etyczne aspekty badań społecznych. Człowiek $i$ Społeczeństwo. T. XXIV. Poznań: UAM, ss. 29-42.

Wiśniewski, R. 2016. Wartość absolutna a problemy moralnej praxis. W: Janeczek, S. i Starościc, S. red. Etyka. Część II. Filozoficzna etyka życia spetnionego. Seria wydawnicza: Dydaktyka Filozofii. Lublin: KUL, ss. 597-612. Witkowski, L. 2007. Między pedagogika, filozofia i kulturą. Studia, eseje, szkice. T. III. Warszawa: IBE. 
Woźniakowski, J. 1988. Czy kultura jest do zbawienia koniecznie potrzebna? Kraków: Znak.

Znaniecki, F. 2001. Ludzie teraźniejsi a cywilizacja przyszłości. Warszawa: PWN.

\section{Intercultural education as spiritual exercise. Pedagogical dimensions of shaping spiritual culture and under- standing supracultural values in the context of religious diversifi- cation and ideological pluralism}

Abstract: It has been assumed in programme statements concerning intercultural education that, among its basic goals and duties, there is also the search for universal values and developing the skill of intercultural communication. This requires going beyond the borders of the own culture, entering multicultural borderlands of religious diversity and ideological pluralism. What is also taken into account is the spiritual transformation which should take place in a person who applies the goals and obligations of intercultural education as the own, a person who aims at their implementation and, due to this, exercises the skills indispensable for participation in intercultural relations. Moreover, it seems that owing to this, this person can become "internally richer". The set of beliefs which constitute the foundations of intercultural education is compliant with the issues signalled in the title, where classically understood spiritual exercising is mentioned and "supracultural values" (values viewed as universal) are focused on.

The pedagogical thought of Tadeusz Kotarbiński is referred to - combining the improvement of spiritual culture (manifested e.g. in the openness to universal values and issues) with shaping "jointly rational people". The ways of understanding the truth, good and beauty - the values considered "supracultural" and shaping the persons' spiritual life have been recognized as the leading issue, which can also become an object of spiritual exercise and a form of practising intercultural education. The significance and role of these values are analysed in the context of multiculturalism, borderland, religious diversity, ideological pluralism and competences enhancing intercultural communication - the aspects on which intercultural education focuses. This context comprises some questions, raised by e.g. Władysław Stróżewski, about understanding the values which are considered to transcend the limits of a particular cultural formation (transcultural values). The reflections oriented in this way should contribute to the further development of the Polish concept of intercultural education. They can be understood as an example of co-acting of pedagogical and philosophical thought, as their joint con- 
tribution to intercultural education. These reflections might encourage to develop the philosophical and axiological reflection upon the problems undertaken by intercultural pedagogy and education.

Keywords: intercultural education, spiritual exercise, developing spiritual culture, universal (supracultural) values, multicultural borderlands

Translated by Agata Cienciała 